\title{
Vine-growing in Catalonia: the main agricultural change underlying the earliest industrialization in Mediterranean Europe (1720-1939)
}

MARC B A D I A-M I R Ó AND E N R I C T E L LO

Economic History, Faculty of Economics and Business, Universitat de Barcelona, Av. Diagonal, 690,Barcelona, Spain, mbadia@ub.edu

We present a model of vine-growing specialization that explains the key agricultural change carried out before and throughout the Catalan industrialization. The results confirm the role played by a "Smithian" market-pull force exerted from the Atlantic demand, together with the "Boserupian" population-push on land-use intensification. They jointly put in motion a process of opening and closing of an inner frontier of vineyard planting, whose local impact was conditioned by the agroecological endowments as well as to the different levels and trends of income inequality. Vineyard planting gave rise to less inequality up to the 1820 s, but it grew again afterwards.

\section{Introduction}

We present an intensive frontier model to explain vine-growing specialization in Catalonia, and the municipalities of the province of Barcelona, which is deemed to be the key agricultural change that preceded and accompanied industrialization. This is a relevant case, given that the province of Barcelona was the earliest industrialized region in Southern Europe. In 1860, industry contributed 37 per cent of value added and employed 32 per cent of active population, compared with 47 percent in the UK and 24 percent in the whole of France. With 1,847 per capita GDP (1990 GK \$US), the Barcelona province ranked above the average figures of Germany $(1,639)$ or Austria $(1,778)$ and just below France $(1,892)$ of the time.

Table 1. Comparative levels of GDP pc in different European nations and the province of Barcelona in 1860

\begin{tabular}{l|cc|}
\multicolumn{1}{c|}{ Nations or regions } & GDP pc 1860 & \\
& (\$US 1990 Geary Khamis) & Population (x 1,000) \\
\hline United Kingdom & 2,830 & 28,888 \\
Netherlands & 2,377 & 3,318 \\
France & 1,892 & 37,300 \\
Barcelona province & $\mathbf{1 , 8 4 7}$ & $\mathbf{7 2 6}$ \\
Austria & 1,778 & 4,235 \\
Switzerland & 1,745 & 2,510 \\
Germany & 1,639 & 36,049 \\
Catalonia & 1,415 & 1,674 \\
Spain & 1,236 & 15,642 \\
Sweden & 1,195 & 3,824 \\
Source: Our own, based on (Rosés et al., 2010; Maddison, 2010).
\end{tabular}

Source: Our own, based on (Rosés et al., 2010; Maddison, 2010).

In spite of being a small sprout that remained rather isolated, its success becomes particularly interesting precisely because of being an early industrializing exception in a Mediterranean environment where the typical mixed farming of the Atlantic bioregion was not feasible due to the 
lack of precipitation and soil moisture (González de Molina, 2005). Vine-growing offered away out to these agro-ecological constraints and became the most important agricultural transformation behind the industrial growth of Catalonia, to which it contributed by increasing the purchasing power of cheap textiles in the domestic market; by generating landowner's savings that helped to finance the new cotton factories; and as a relevant export item that allowed to purchase raw materials and machinery abroad (Sánchez and Nadal, 1998a; Sudria and Pascual, 1999; VallsJunyent 2007; Marfany, 2010; Marfany, 2012).

Our model tries to understand how this comparative advantage arose from a set of interrelated factorsnamely the environmental endowments, the connection with the Atlantic trade, the push of population growth toward more intensive land uses, and the evolution of income inequality. In the following sections, we will contrast the stylized facts of this historical process with some static theoretical insights, such as Hecksher-Ohlin and Stolper-Samuelson models. Amore dynamic view will be adopted, based on the process of opening and closing of an inner frontier of vineyard planting that moved along the Ricardian intensive margin of the prevailing agricultural system.

\section{An inner-frontier model of vineyard spread}

Grape vines had been grown in Catalonia for many centuries before becoming a cash crop. They were traditionally planted as a temporary cultivation in former small plots of woodland or scrub slashed and burnt (a task called rabassa in Catalan), until the vines became too old and the vineyard was left to be reforested. Another crop pattern consisted of planting sparse rows of vines with strips of arable land in between, which were alternatively sown with grains or left fallow. These traditional vine-growing had long existed as a complementary side into many Mediterranean polycultural landscapes that produced wheat, wine and olive oil in poly-cultural landscapes mainly oriented to local markets. As in other European places, there were several inner regions of Spain where land was mainly allocated to this kind of traditional viticulture that sold wine to other graingrowing, livestock raising, or fish-catching areas—such as the lands along the Duero River, La Rioja and Navarra that traded with the Northern Cantabrian coast, or in Castilla-La Mancha that supplied wine to Madrid (Ringrose, 1970; Pan-Montojo, 1994; Simpson, 1995; Carmona et al., 2001; Simpson, 2011). High transportation costs before the fossil fuels era entailed that most of these wines were only traded regionally (Simpson, 2011).

Other Mediterranean coastal places exported to the North Atlantic economy luxury wines like in Malaga, Jerez, or Porto. However, while the British consumption of these port-like wines remained flat from 1815 to 1914, the imports of cheap Spanish white table wines soared from some 7 million $\mathrm{hl}$ in 1825 to nearly 30 million $\mathrm{hl}$ in 1875 (Simpson 2011). Catalonia produced and sold these 
kinds of cheap liquors and wines oriented toward a massive elastic demand, able to carry out a deep transformative process in the regional economy with low entry barriers

This export-led spread of new vineyards started at the end of the $17^{\text {th }}$ century, when the Dutch trade connected the Western Mediterranean coast with the emerging Atlantic economy (Torras, 1996; Valls-Junyent, 2003), and increased during the $18^{\text {th }}$ and 19th centuries until the Phylloxera Plague, which initially fostered new plantations from 1867 onwards before ravaging all Catalan vines from 1879 to 1890 . In 1858 there were 115,454 hectares of vineyards in the province of Barcelona, which accounted for 51 per cent of farmland to which some additional 16,000 hectares were added until the Phylloxera crisis (Badia-Miró et al., 2010). Vineyards were planted through an almost-emphyteutic contract called rabassa morta (as the sharecropping was meant to come to an end when two-thirds of the vines had died), being offered by the landowners to small growers with little or no land of their own (Vilar, 1962; Giralt, 1965; Balcells, 1980; Carmona and Simpson, 1999; Colomé, 2000; Garrabou et al., 2000; Badia-Miró et al., 2010).

\subsection{Long-term trends in relative prices}

At first sight, the theoretical background underlying this historical narrative could be considered an applied version of the Heckscher-Ohlin model. According to it, vine-growing specialization would have developed in those Catalan municipalities with more favourable factor endowment to meet the increasing foreign demand for liquors and wines. However, this is a static theorem that requires a strong ceterius paribus assumption. We are instead talking about a long-term historical process of dynamic specialization that cannot be simply understood as a punctual reallocation of land and labor endowments according to more profitable options to trade abroad. We know, for instance, that from 1680 to 1935 the relative price of Catalan wines in terms of wheat did not always evolve in favorable terms to replace cereal lands with vineyards (Figure 1). 


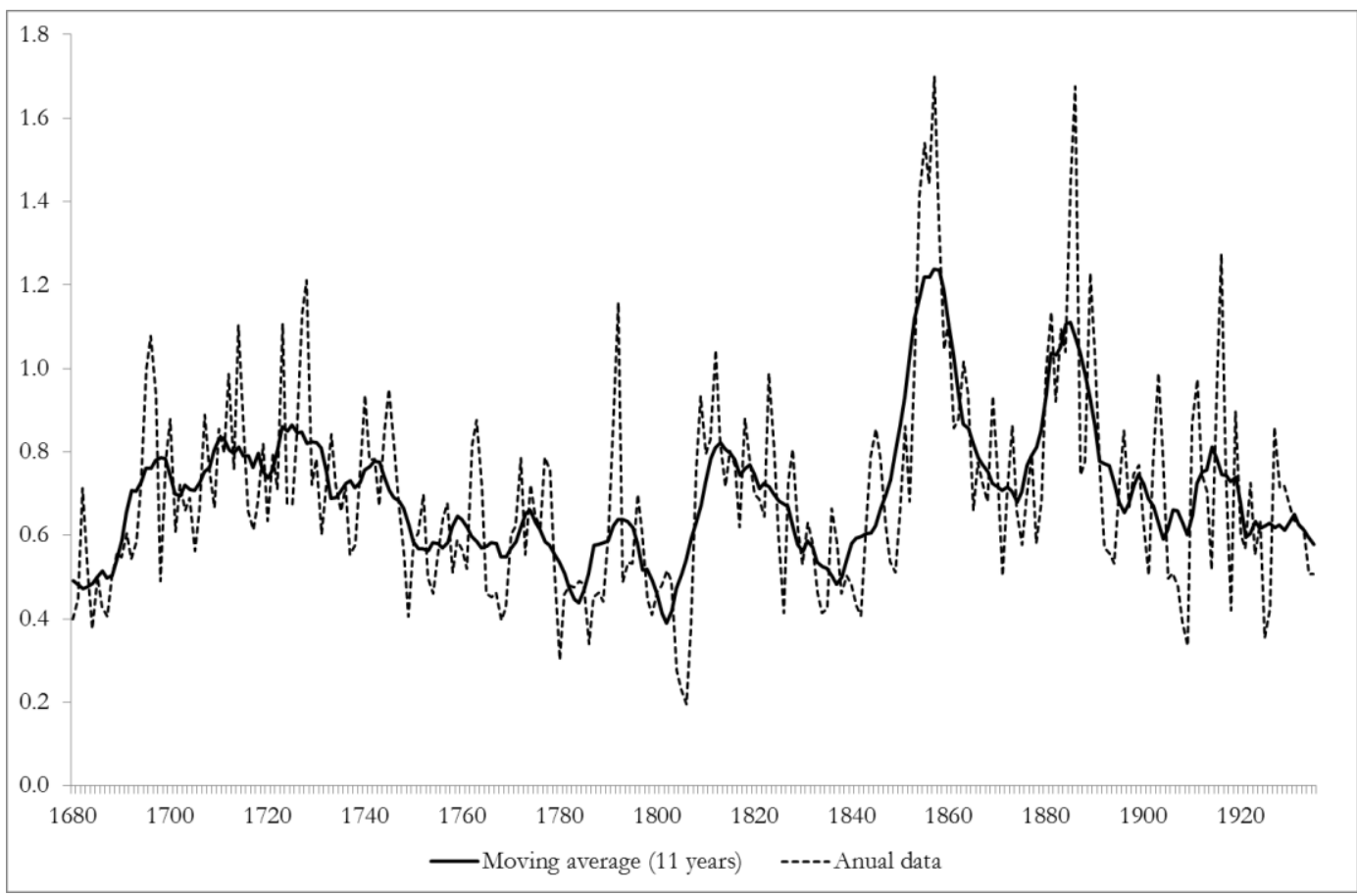

Source: (Colomé et al., 2013).

The long-termevolution in the terms of trade (see figure 1), and its high volatility in the short term, set the level of risk assumed by vine-sharecroppers who, after giving up self-sufficiency, had to buy their staple food in the market with the cash earned selling grape vintages. It is very significant that the planting of vines through rabassa morta contracts did not stop, but even increased during the second half of the eighteenth century, or in the 1830 and 1850s, in spite of the falling trend experienced by the relative prices of wine (Tello, 1995; Garrabou et al., 2009; Garrabou et al., 2010; Colomé et al. 2013).

\subsection{Combining Smithian pulling and Boserupian pushing forces in a vine-planting frontier}

Figure 2 outlines the set of variables and conditioning factors we propose to consider in our model. It highlights the Boserupian pushing force of increasing population densities that triggered more intensive land uses (Boserup, 1981; Boserup, 2005; Netting, 1993; Valls-Junyent, 1997; Hunt, 2000; Colomé at al., 2010). This, in turn, combined with the Smithian force exerted by a growing demand of cheap wines, and jointly induced a reallocation of land and labour towards vine-growing. The population-pushing and market-pulling forces had different impacts on the local land-use changes, depending on two other sets of conditioning factors, namely the specific agro-climatic endowments and the existence of a labour force ready to enter into tenancy contracts to grow vines. Some of 
these factors can be regarded as naturally given, such as agro-climatic endowment. Others depended on human agency within a dynamic socioeconomic context, such as migrations and demographic behaviour, that changed population densities, or the readiness of many landless peasants to invest their labour force to turn poor sloping land into terraced vineyards. In other words, we are assuming an agency-oriented explanation of a historical process of land-use change fostered by the opening and closure of an inner vine-planting frontier.

Figure 2. Pushing or pulling drivers and conditioning factors of Catalan vine-growing specialization

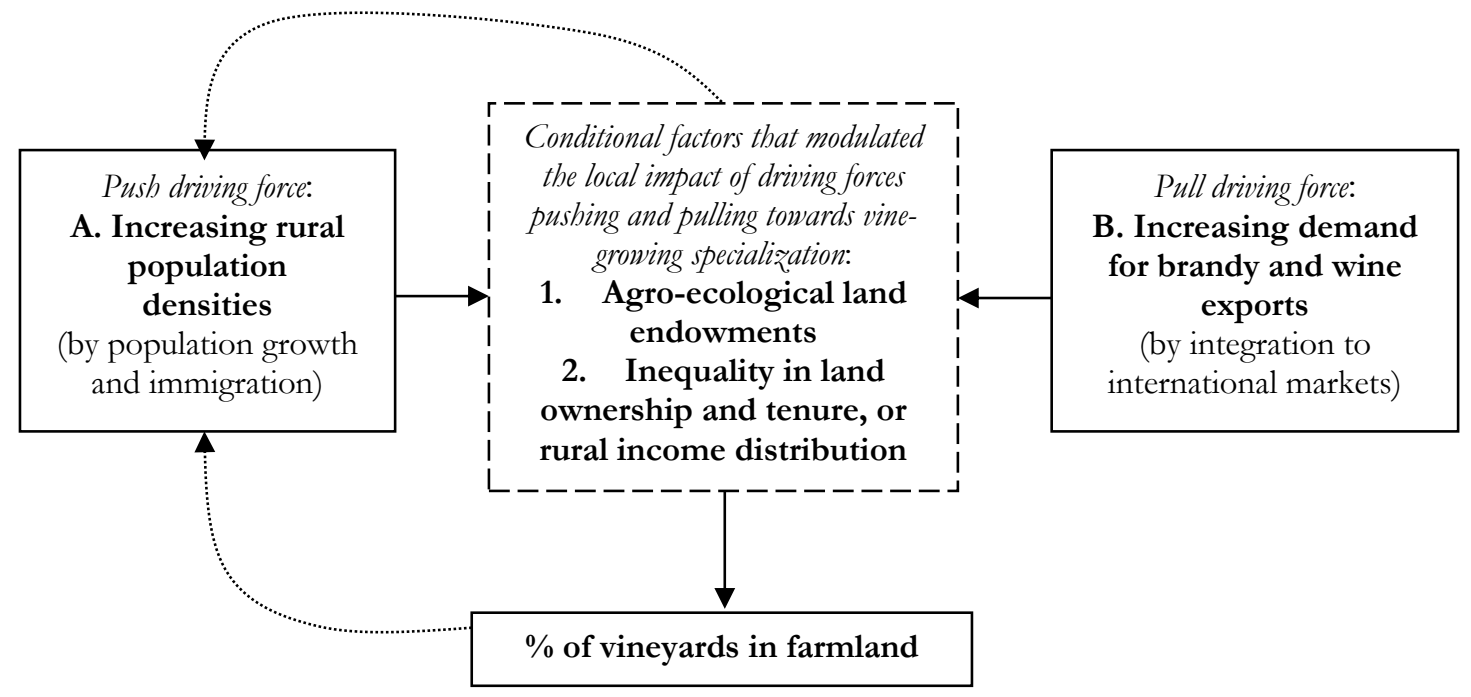

Source: Our own, based in (Garrabou et al., 2009; Badia-Miró et al., 2010).

What eventually mattered was the dynamic junction of these drivers and conditioning factors. The American and North European demand for spirits and wines pulled a new commercial type of winegrowing in Catalonia (Vilar, 1962; Valls-Junyent, 2003), while population growth made it necessary to adopt more intensive land-use patterns so as to overcome fallowing and get increasing incomes in smaller plots. This wine-exporting specialization brought about the most important change crop allocation experienced in Catalonia before and during industrialization, and it entailed a deep effect on the composition and evolution of foreign trade. From 1865 to 1889 1889, some 40 percent of the total Spanish exports were vine products (Simpson, 1995; Torras, 1996; Carmona et al., 2001; Valls-Junyent, 2001; Valls-Junyent, 2003; Pinilla and Ayuda, 2007). This, in turn, led to relevant changes of rural income distribution in the Catalan economy.

\subsection{The rental-wage trends in vine-growing and cereal-cropping areas}

Which was the long-term relationship between income inequality and vine-growing specialization in Catalonia? While the opening of a vine-planting frontier offered a provisory way of access to land 
for many poor landless peasants, the increasing reliance on distant markets affected the risks taken by vintners and had an impact on income distribution as well. Who in the end got the incomes gained through the spread of this cash crop? The answer is far from simple, and the available evidence is rather scant so far (Colomé, 2000). To fill this gap we have calculated the rental-wage ratio in two historical series carefully selected to correspond either to mainly cereal-growing or to vine-growing places. These Williamson's indices are only aimed at highlighting the long-term trends of rural income inequality experienced in Catalonia, and by no means can be taken as an accurate account of the gains actually obtained by the rabassa tenants or their landowners. The key point is that, according to the available evidence, rental-wage ratios followed very different trends in vinegrowing lands than in grain-growing areas (Figure 3).

Figure 4. Rental-wage ratios in cereal growing (left) and vine-growing (right) Catalan areas, 1720-1900
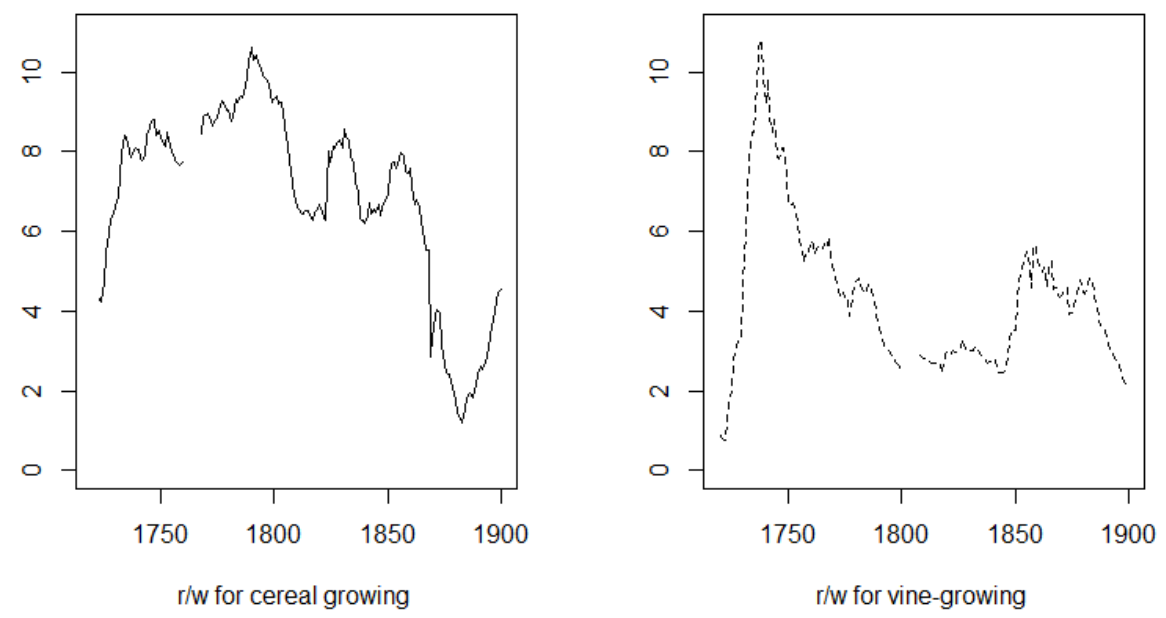

Source: Our own.. For a detailed descrption, see appendix.

During the economic depression after the Catalan defeat in the Succession War, (1701-1714) followed by the imposition of a cadastral land tax initially intended to collect war reparations from the vanquished kingdoms of the Aragon Crown, the payment of land rents dropped almost to nothing due to arrears - given that croppers delayed a great deal of rent payments until they were able to keep themselves abreast in the following years. The unskilled rural wages could not be further reduced instead, as they were near to a bare-bones subsistence level. This combination shrunk the rental-wage ratio for a while (Figure 3). Then, when the economic recovery during the 1720s resumed the land rent levels previous to the war, the high relative prices of wine opened for the landowners a feasible way to resist the new tax burden by offering to landless people marginal plots to plant vineyards (Figure 1). In exchange with salted fish brought by Dutch traders from the Atlantic, the Catalan landowners were able to earn through the export of distilled spirits the cash they urgently needed. 
In earlier times whenever these Catalan landowners required some amount of cash they used to resort to rabassa morta contracts. Their synchronized response from 1720 onwards opened a true Ricardian inner-frontier of land-use intensification pulled by the Smithian growth of the Atlantic economy. The rabassa morta practice avoided them the entire plantation costs, while the sharecropping terms of the contract allowed capturing the fast upswing of the rental-wage ratio that ensued from 1720 to 1740 . We can wonder why then, after having put in motion a vineplanting frontier, the Catalan landowners did not shift to a direct management by assuming themselves the cost of plantation and the farming of the vineyards by using day-laborers. This behavior can be related to the fall of rental-wage ratios that ensued after 1740 (Figure 3). ${ }^{1}$

The advance of the Catalan vine-growing frontier was very impressive: at the end of the $18^{\text {th }}$ century, two thirds of Spanish liquor exports came from Catalonia, and the other third from Valencia (Torras, 1996). Nevertheless, from 1740 onwards relative prices started to move against selling grapes to buy wheat (Figure 1) in a persistent trend that played a role in the following diverging paths in rental-wage ratios. While in cereal-growing areas Catalan landowners kept or even increased their land rents at the expense of croppers' wages, in vine-growing places rentalwage ratios experienced a significant downturn until the end of the $18^{\text {th }}$ century (Figure 3).

To what extent can we assume from these Williamson's indices that income inequality decreased in vine-growing Catalan areas during most of the eighteenth century, while it was maintained or increased in cereal-growing lands? A rural class of laborers completely dependent of wage earnings was almost inexistent in Catalonia. The earners of the wages plotted in Figure 3 were mainly smallholders or landless sharecroppers who hired out their labour surpluses part-time. At the same time, the rabassa morta contracts entailed a sharecropping arrangement that linked the incomes gained by both sides to the fate of market prices and returns-albeit not in an equal manner.

\footnotetext{
${ }^{1}$ A main reason that explains why day labourers were so seldom hired in Mediterranean arboriculture is moral hazard. Vines, like many other tree crops, can be heavily damaged if pruning, ploughing and hoeing are badly performed (Simpson, 2011). However, a relevant share of the Catalan landowners were also farmers that could rely on their family labour force to carry out these skilled tasks and only resort to day laborers during vintage, like many French vintners did after becoming owners of their vineyards after the Revolution.
} 
Behind this question there lies the very complex social and agro-ecological fabric of this inner vineplanting frontier opened in Catalonia, in which almost all parts involved made a living by assembling different kinds of incomes and earnings. Besides being sharecroppers and part-time labourers, some of these vine-growers could also have some plots of their own. As such, they could take a share over the total gains obtained through the export-led growth of wine spirits or table wines. But the general trend followed by their always mixed incomes had to be kept in line with the rental-wage ratios, at least to some extent, simply because these agricultural minimum wages were the opportunity costs taken into account for the landowners who leased rabassa morta contracts, as well as for the sharecroppers that accepted them.

Keeping this in mind, we deem the persistent downward trend of income inequality from 1740 up to the end of the $18^{\text {th }}$ century to be reliable, and also coherent with land-saving as well as a laborintensive biological innovation induced by the new Atlantic trade opportunities. However, as Hayami and Ruttan (1971) pointed out, the result in terms of income distribution always depends on what happened at the same time with population growth. During this first phase of the process, the Smithian market force would have pulled stronger to the advance of the vineyard frontier than the Boserupian pushing exerted by the increasing population densities in Catalan rural areas. While the Ricardian frontier of land being offered to new vine-growers advanced at similar or even faster pace than rural population densities, rental-wage ratios fell and income inequality was lowered in wine-growing areas compared with other places where land being devoted to grow cereals or to forestry did not expanded in the same way. Provided that the demand for liquors and wine was kept growing, landowners would go on offering new rabassa morta contracts even though they had to accept that the constant share taken over the sharecroppers' vintage would be paid with lower relative prices and would led to relatively lower rents than in arable land sown with cereals from 1740 to 1800 . Under these circumstances, during most of the $18^{\text {th }}$ century the export-led growth of viticulture helped to reduce income inequality in the Catalan vine-growing areas.

\subsection{A social and ecological geography of vineyards}

However, there seems to be something apparently odd about these trends. Why the Catalan landowners did not shift to grow cereals, instead of keeping on the offer of rabassa morta contacts to plant vines, once the relative price of wine in terms of wheat fell from 1740 to 1800 ? The answer is that they did both things (Garrabou et al., 2012). They allocated to cereal crops their own flatter and moister lands, and only leased to vine-growing sharecroppers tiny plots in the poorest, dryer and sloping soils less profitable to grow grains. Another relevant feature of this vineyard specialization was that the typical medium-size landholdings (called masies in Catalan) kept a polycultural crop pattern that allowed the landowners to reduce risks by maintaining the option to enter 
or exit the market depending on the circumstances (Pascual, 2000). Their sharecropper-vintners, on the contrary, found themselves completely at the mercy of market volatility.

Therefore, we are talking about a partial vineyard specialization amidst a poly-cultural landscape far from a monoculture. This very important feature was also related to the shifting location of Catalan vineyards. In the province of Barcelona the vines started to be planted as an export cash-crop in the outskirts of the city and along the neighbouring coastal counties. From these littoral locations, the vine-growing frontier expanded across the pre-littoral corridor and towards the North, while at the same time many periurban landowners shifted again to cereal cropping from 1740 onwards (Vilar, 1962; Badosa, 1985; Valls-Junyent, 1996; Paül, 2010). In mid-19th century there was a first agricultural ring around Barcelona and other cities devoted to grow vegetables and cereals, following a typical von Tünen pattern. The vineyards had been displaced towards many intermediate fringes between the cereal plains and forested mountains (Map 1).

\section{Map 1 - Municipal proportion of cropland allocated to vineyards in 1858 (left) and roughness of the land (right)}

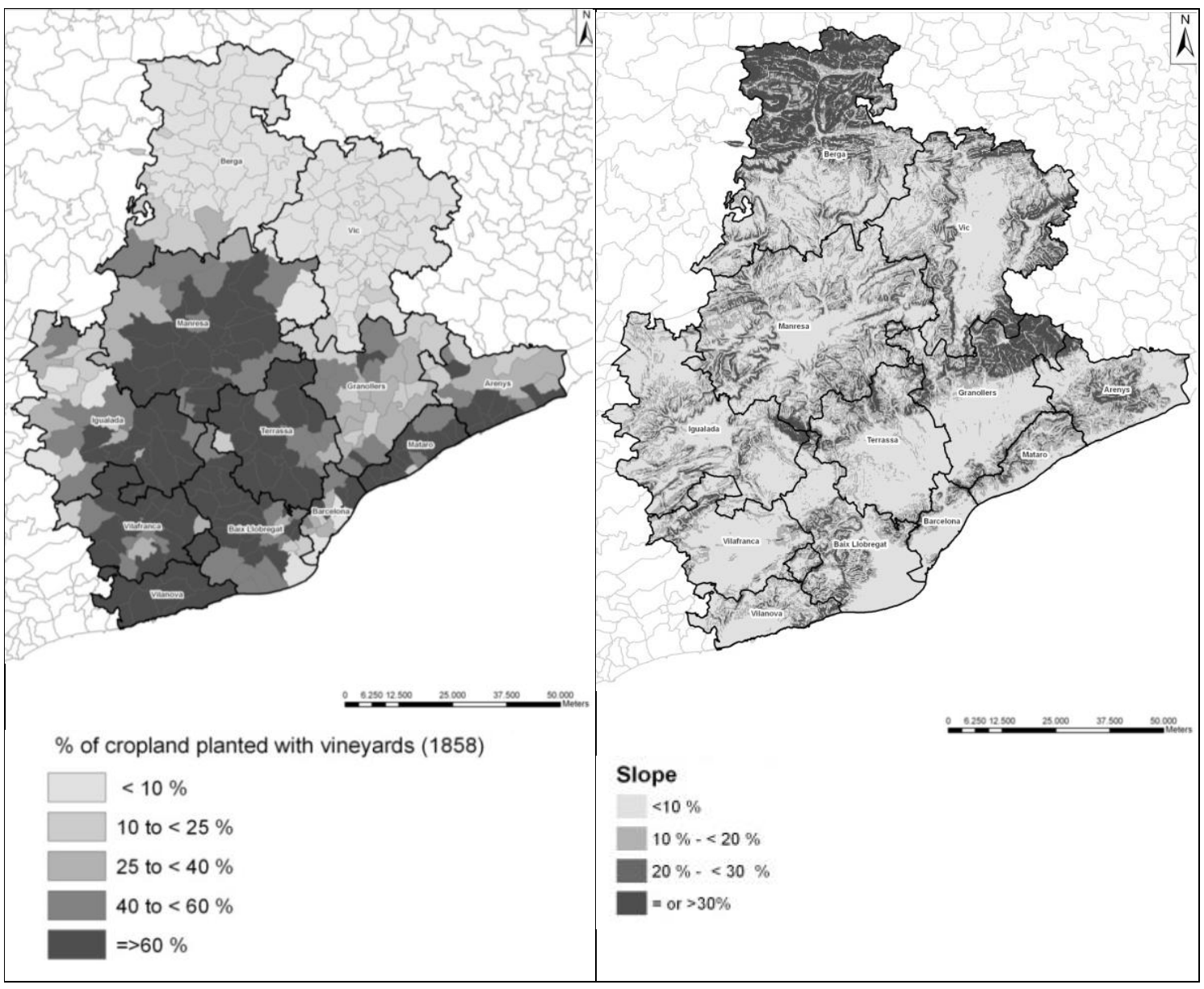

Source: Our own, from the Estadística Territorial (Muro et al., 2011) and digital elevation map. 
As a result, while the province of Barcelona exported ever greater amounts of liquors and wine (a labour-intensive product), and imported wheat in return (a much more land-intensive product), a share of its own staple food was still locally grown. Circa 1860 the local production of cereals yielded about 15-16 hectolitres per hectare and was cropped in $44 \%$ of farmland, so that local production of food grains could fulfil $39 \%$ of the consumption. To cover the other $61 \%$, one million hectolitres of wheat per year had to be imported (Map 2).

Map 2 - Population densities and shortage or surplus degrees in cereal food production to meet local consumption in the municipalities of the province of Barcelona (1859-67)

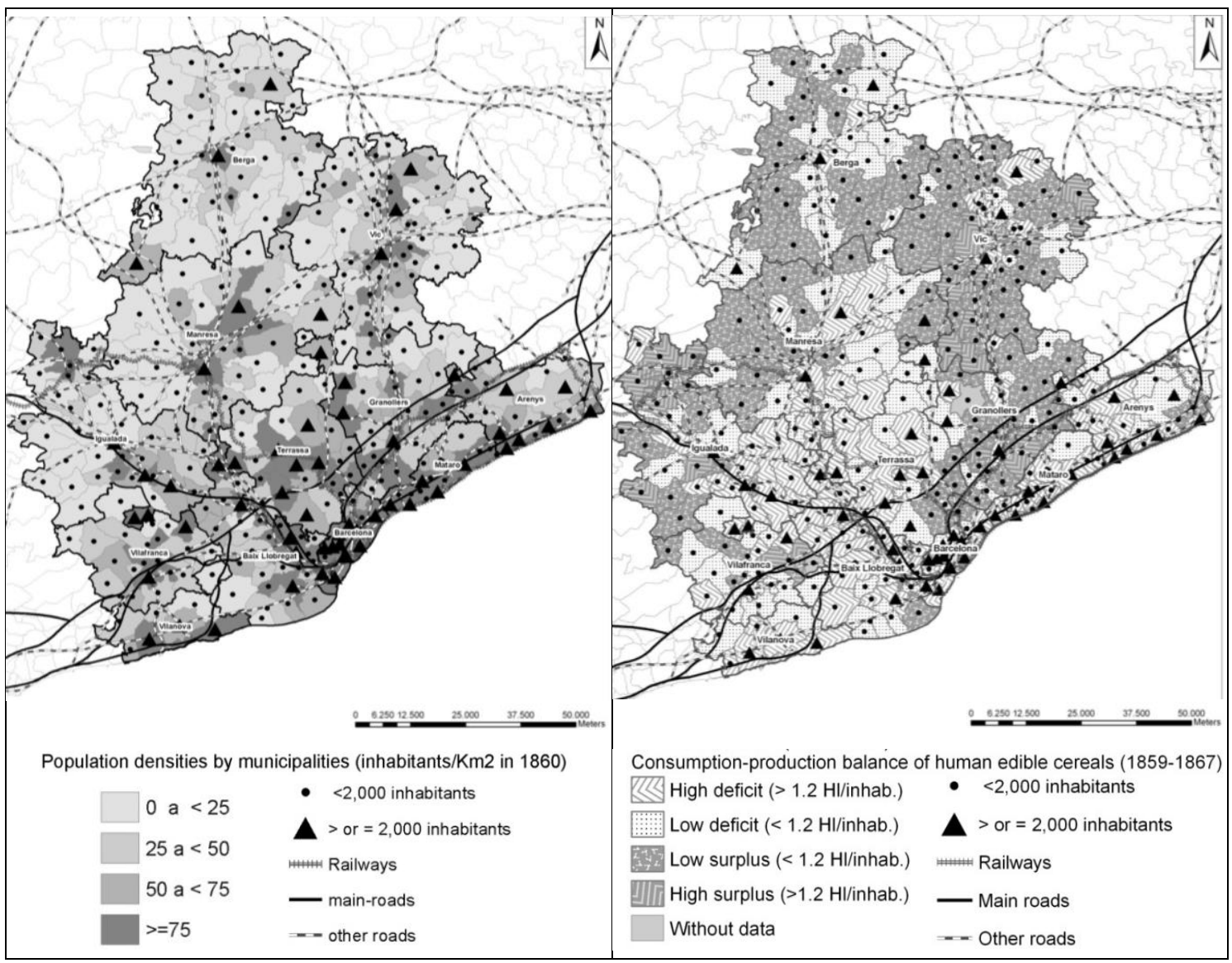

Source: Our own, from the Centre d'Estudis Demogràfics (http://www.ced.uab.es/index.php) for the population data. We thank to the Barcelona Institute of Regional and Metropolitan Studies (IRMB-UAB) for facilitating the digital information on the road and rail networks in 1860. The dependence degrees on staple food imports have been drawn from the dataset compiled with the Estadistiques de la producció $i$ consum de cereals als partits judicials de la provincia de Barcelona (National Library of Catalonia, Archive of the Commercial Board, lot CXXVI, boxes 163 and 164).

\subsection{The closure of the vine-planting frontier and the landowners' reaction}

From the end of the $18^{\text {th }}$ century up to the 1840 s, the rental-wage ratio remained stable at its lowest level, whereas in cereal-cropping Catalan places grew from 1820 to 1830 and fell again to the previous level in 1840 - a period when wheat imports were banned in Spain. We believe it was over this period that population growth started to overflow the absorption capacity of the Catalan vine- 
planting frontier. While this happened only in some villages, the surplus population could still migrate to other areas where the frontier remained open. But we guess that from the end of the eighteenth century onward the frontier moved increasingly slowly, and tended to stop during the first decades of the nineteenth century just before the two big vine-growing booms arrived in the 1840 and 1870s. The rise in relative prices of firewood and charcoal, fostered by the deforestation ensuing vineyard spread, also tended to increase the opportunity cost of additional vine planting in forestlands. The following vine-planting cycles of the 1840-50 and 1870-80s could have hardly taken place without the increasing reliance on coal imports (Vilar 1962; Nadal et al. 2012).

The closure of the vine-planting frontier tended to turn the former Boserupian relationship between population density and land-use intensification into a Malthusian one (Colomé et al., 2010), unless industrial activities increasingly based in fossil fuels came to the rescue. Put in another way, during this second phase of the process the population pushing tended to overflow the pace of the Smithian pull, thus starting the closure of the Catalan vineyard frontier moving along a Ricardian intensive margin. As a result landowners increased their bargaining power against the vine-growers, and tried to change in their favour the prevailing terms of the rabassa morta contracts. To do so, the Catalan landowners took advantage of the liberal agrarian reforms being introduced in Spain. The duration of the contract and the rent share over the vintage became highly contested issues of a strong social conflict that lasted from the end of the eighteenth century until the end of the Spanish Civil War in 1939 (Balcells, 1980; Tello, 1997; Carmona and Simpson, 1999).

The initial rabassa morta contracts established a very long lease that lasted until the vines' death, and the sharecroppers took advantage of the traditional layering system to renew their vineyards (Simpson, 2011). This way, all vineyards could be kept alive, rendering their access to the land almost permanent. The landowners reacted by asking the courts to dictate a fixed term of fifty years for the completion of the contract, as was sentenced for the first time in 1765—a decision that lead to a first wave of protests by the rabassa morta sharecroppers along the crisis of the Catalan viticulture during the closing of liquor exports during the wars with France.

The ensuing process of agrarian liberal reform opened or closed opportunity windows either for the rabassa morta sharecroppers or their landowners, depending on the political swing between democratic or oligarchic undercurrents. For three brief democratic moments, the Catalan vintners were near to attain their aim to become fully owners of the vineyards, like in France after the Revolution. In 1820 during the Liberal Triennium, and again in 1873 during the First Spanish Republic, laws were passed that offered to them the opportunity to redeem any kind of emphyteutic contracts still in force like the. In 1820 during the Liberal Triennium, and again in 1873 during the First Spanish Republic, laws were passed that offered to the croppers the opportunity to redeem any kind of emphyteutic contracts still in force like the rabassa morta. Finally, 
in 1934 the autonomous Catalan Parliament restored by the Second Spanish Republic passed a law that gave full satisfaction to the claims of the Unio de Rabassaires founded in 1922. However, all these democratic attempts were defeated by the absolutist restoration of 1823 , the oligarchic parliamentary regime settled from 1873 onwards by the second monarchic restoration, and the fascist regime imposed by the general Franco in 1939.

During the much longer periods ruled in a favourable manner for the landowners, the Civil Code of 1851, finally approved and enforced in 1889, established a fixed term of 50 years for the new rabassa morta contracts and opened the way to evict the sharecroppers after the expiry of the tenancy. What has been called 'denaturalization' of the original rabassa morta contract ensued (Figures 4 and 5), followed by an increasingly stronger movement of protest by Catalan vine-growers.

Figure 4. The substitution of rabassa morta contracts with a fixed lifespan in sharecropping leases during the nineteenth century in the Penede's County.

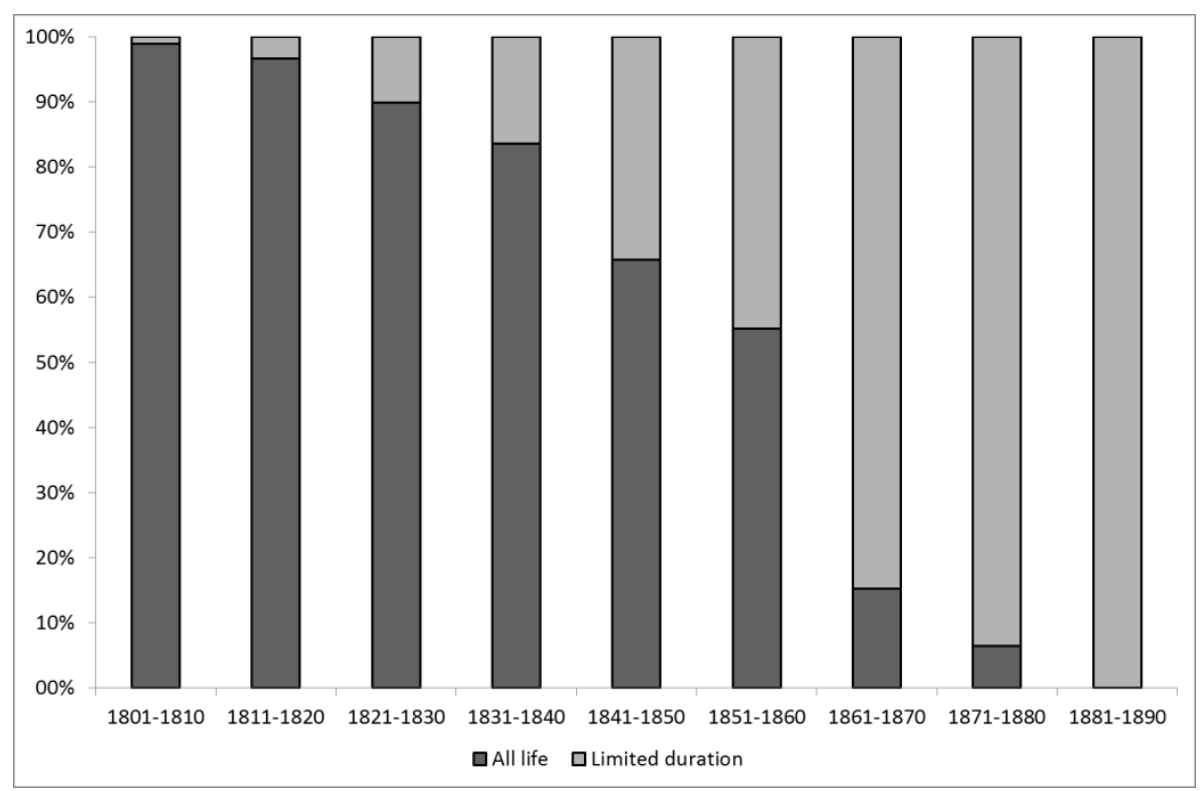




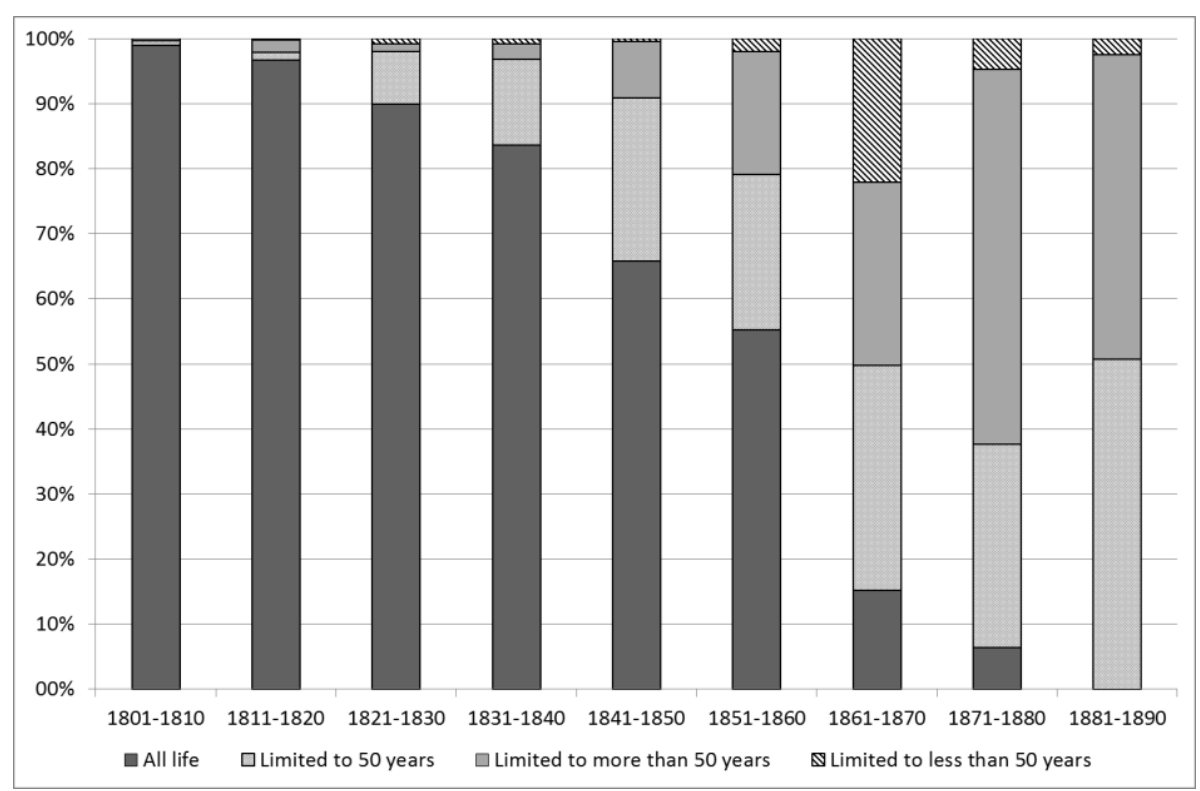

Source: Colomé (2013).

Figure 5. The average share of vintage paid to the landowner in the municipality of Piera

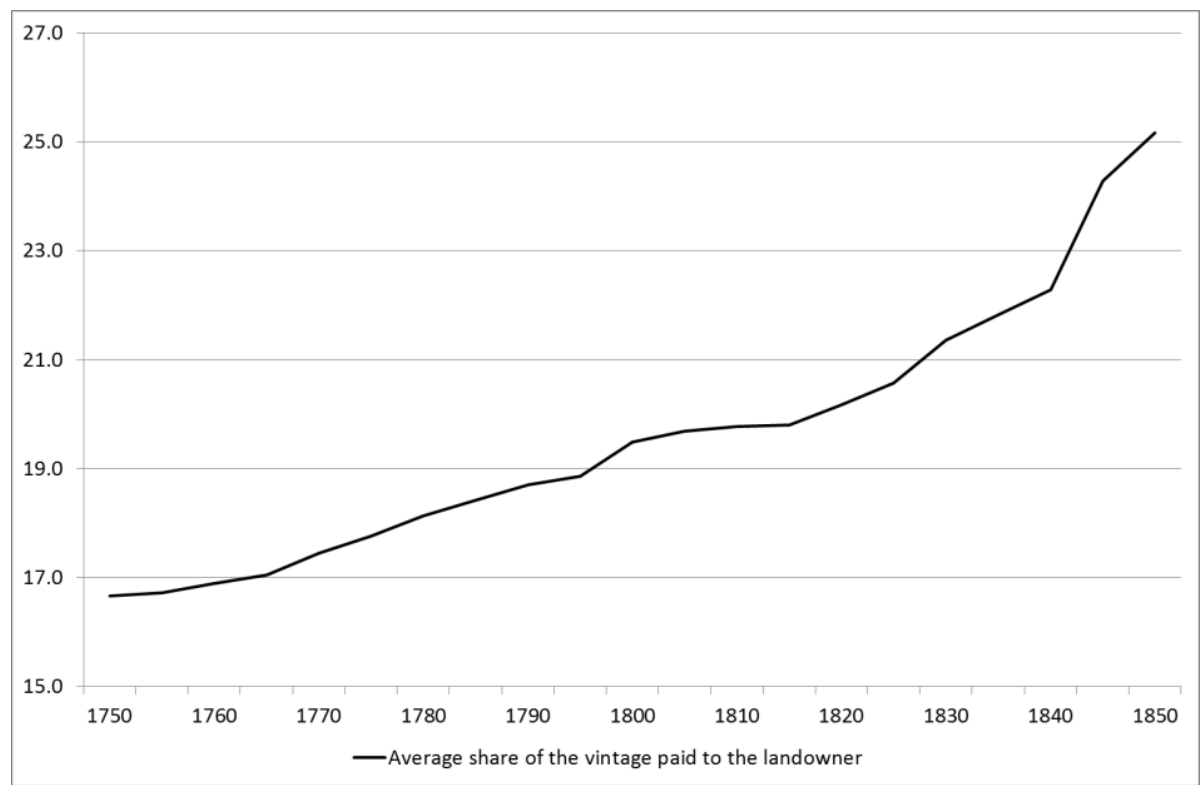

Source: Valls-Junyent (1996).

Once the difficulties of the Napoleonic Wars were overcome at the end of the 1820s, the Catalan viticulture thrived during a first boom of relative prices of wine during the Odium mildew in the 1840s, and during a second boom from 1875 to 1885 when the Phylloxera plague had destroyed the French vineyards but not yet all the ones in Catalonia (Figure 1). The landowners faced these new market opportunities with lower land-labour ratios increasingly favourable to their bargaining power, which was also reinforced by the liberal agrarian reforms. It is hardly surprising that they were able to take almost all the gains of these upward trends in relative prices (Figures 4 and 5). Agricultural wages did not, and income inequality tended to increase again in Catalan vine-growing 
areas throughout most of the $19^{\text {th }}$ century. Conversely, in cereal-growing areas, land rents remained fairly stable while agricultural wages, which had been lower in the inland arid planes, tended to converge with coastal labour earnings from 1860 onward (Garrabou and Tello, 2002).

The fall of the rental-wage ratios in cereal growing areas became even more pronounced by the effects of the overseas 'grain invasion' from 1870 onward (Offer, 1991; O'Rourke and Williamson, 1999), a trend only partially offset by the devaluation of the Spanish currency followed by the strong protectionist tariffs of the 1890s (Figure 3). This downturn also helps to understand the strong clash for income distribution between farmers and landowners during the agrarian crisis of the turn of the century (Koning, 1994), when the rental-wage ratios fell both in cereal-growing and vine-growing areas. Most Catalan wealthy landowners tried to play with all the cards in the deck under the Spanish protectionist umbrella by keeping their farms poly-cultural ( Pascual, 2000). This behaviour had allowed them to download in a great deal the former downturns in relative prices of wine on the shoulders of their vine-growing sharecroppers, who were also part-time laborers. This was no longer possible when all agricultural prices started to fall. The increasing integration of labour markets could also raise a bit the opportunity cost and strengthen the bargaining capacity of vine-croppers at that time, some of whom renounced to their rabassa morta contracts voluntarily to search for a job in the nearby industrial factories. ${ }^{2}$

Seen in a long-term historical perspective, the reaction of Catalan landowners after the closure of vine-planting frontier and the ensuing upward trends experienced by the rental-wage ratios (Figures 3, 4 and 5) fit quite well with the strong social unrest and political polarization found within many Catalan rural communities which relied on viticulture during the second half of the $1^{\text {th }}$ century and along the first third of the 20 th century (Planas and Valls-Junyent, 2011; Planas, 2013; Colomé, 2013). We may consider that, together with Smithian, Ricardian and Boserupian variables, the Marxian driving force of class struggle also played a role in this process.

\subsection{Long-term impact of the vine-planting frontier: a fall and rise of rural inequality}

The results found in the long-term trends of Catalan rental-wage ratio (Figure 3) are at odds with the assumptions made by the Stolper-Samuelson model. Following a Heckscher-Ohlin approach,

\footnotetext{
2 An interesting aspect brought into light by our inner-frontier model of vineyard spread is the relationship between the offering of land tenancy contracts to plant vines and the opportunity cost of labouring people in industrial labour markets. Could it be that at the dawn of Catalan industrialization a vine-planting frontier that still remained open could have increased the opportunity cost of workers, helping to raise wages and the corresponding incentive to introduce labour-saving machinery? Conversely, could it be that once the vineplanting frontier had definitely been closed, labour demand in an increasingly mature industry could have contributed to increase the bargaining power of vine-growers in the turn of the $19^{\text {th }}$ century? Of course, both possibilities would depend on the degree of integration of labour markets. This aspect deserves a detailed study in future.
} 
the Stolper-Samuelson theorem states that an increase in relative prices of a commodity will lead to a rise in the return to that factor more intensively used to produce it, and conversely, to a reduction in the return to the other less abundant factor (Lindert and Williamson, 2003; Williamson, 2011). As we are dealing with a highly labour-intensive cash crop, along with the reduction in the relative price of wine experienced from 1740 to 1800 , we should have to expect a rise in the income get by the owners of less abundant land and a fall in the earnings of the more abundant labour. We have found exactly the opposite along most of the $18^{\text {th }}$ century. Then, when relative prices rose again in favourable terms for wine from 1840 up to 1885 , we should expect a fall in the income get by the owners of less abundant land and a rise in the earnings of an increasingly abundant labour. Again we found the opposite.

This outcome can be explained by the static character of these models. They tell us what would have happened during the First Globalization (1870-1914) provided that the convergence in commodity prices, and the factors used to produce them, would not have been counteracted by other driving forces. However, they were counteracted in a great extent by the long-term dynamics set forth by the opening and closure of an inner frontier of vineyard land-use intensification that altered the bargaining power between landowners and croppers. Our frontier-led historical context renders the Stolper-Samuleson theorem much less relevant, and stresses the importance of regional diverging trends within nations-as (Greasley et al., 2007) and (Harley, 2007) point out in a special issue around this topic. ${ }^{3}$

\section{Data sets assembled and expected sign of each variable in mid-19th century}

Our inner-frontier model of land-use change combines what are called first-nature and secondnature variables by Environmental Historians (Cronon, 1991) as well as by New Economic Geography (Krugman, 1993). While agro-climatic endowments are first-nature factors, the dynamic interaction between the other variables becomes a set of second-nature drivers-included timedistances to the nearest seaport that we take as a proxy for the Smithian market-pulling force (Badia-Miró et al., 2010). What really matters is the combination between them in a dynamic process that entails the emergence of feedback loops (like the one that turned into Malthusian an initially Boserupian relationship between population growth and land-use change). This means that except for the pulling market force, all variables had to move along a specific range of values, higher than a minimum but not exceeding an upper level, so as to fit with the rest in an adequate economic factor endowment.

\footnotetext{
${ }^{3}$ Some examples around the evolution of rental-wage ratios could be found in the special issue introduced by Harley (2007)..
} 
According to this, vineyard specialization stopped when one or several key variables exceed certain threshold values, for example, attaining population densities higher than the ones capable to be sustained by a still mainly agrarian economy, or exhausting marginal lands available to plant vineyards. When that time came, people faced a dilemma. Either demographic surpluses started to emigrate towards other places or local economies started a structural change to more industrial activities—or, as it happened immediately after the Phylloxera crisis, the rural families adopted a fast demographic transition towards low birth rates (Colomé et al., 2010; Colomé and Valls-Junyent, 2012). It would be great to carry out this analysis along several dates, in order to assess whether or not the relative weight of first-nature and second-nature variables changed throughout this longterm historical process. Nevertheless, the available datasets only allow us to perform a cross-section analysis in the mid-19th century.

The spatial distribution of vineyards in the province of Barcelona in 1858 (Map 1) shows that vinegrowing municipalities tended to be located either along the coast or covering the fringes between the flatter areas and the sloping hills in the pre-littoral corridor. We also observe a higher presence of vines in areas closer to Barcelona, and lower levels in the municipalities far from the coastalthough there was a first ring allocated for grains and vegetables around the outskirts of the city (Maps 1 and 2). Our model tries to explain these locations by relating the proportion of vineyards in the farmland with the values adopted by the rest of independent variables that appear in figure 2 .

In the context of a vine-planting frontier being extended by a long-term process of market integration of a staple export, the relationship between population growth and land-use change appears to be less obvious than expected. Up to a point, higher population densities fostered more intensive uses of the land, such as vine-growing, but further increases above a certain threshold could put an end to vineyard planting - not only because of the exhaustion of available land, but also due to the need to develop industrious or industrial activities that would increase labour costs. Moving beyond the city of Barcelona and its outskirts, population densities increased from nearly 20 inhabitants per square kilometre in 1718 to more than 36 in 1787, and then doubled again to 64 in 1857-1860. As a result, per capita land availability had reduced from more than five hectares per inhabitant to only one and a half in 140 years.

Map 2 outlines that those municipalities with higher population densities in 1860, together with the capitals of the districts, were clustered in coastal zones around Barcelona, and spread along the rivers. Within this spectrum, an optimal population density for viticulture seems to have been between 25 and 65 inhabitants per $\mathrm{km}^{2}$ (Badia-Miró et al., 2010), a range that fits the upper 
threshold for a rain-fed agricultural economy established by (Boserup, 1981). Only an urbanindustrial economy could host higher population densities, as was the case in the industrializing districts of the Barcelona province. According to these lower and upper thresholds, it is not the population density at a given date that allows us to capture the push driving force exerted by the Boserupian population pressure on land-use intensification. What becomes significant the increase in population densities between some lower and upper thresholds before the change in crop allocation. As we have already checked in earlier versions of the model (Tello et al., 2008), what becomes significant is the growth population experienced along a period of time before the levels of vinegrowing specialization we want to explain were laid down (Garrabou et al., 2009). Therefore, we use population increases from 1787 to 1860 as the Boserupian variable, although population densities in 1787 and 1860 were also used as a contrast.

Market access to a growing Atlantic and colonial economy became a key variable for the impact exerted by this Smithian pulling impulse in different municipalities through the extension of the vine-planting frontier. Our model assesses this pull effect using travel costs to the seaports, as measured in time distances before the arrival of railways. Map 3 shows the stylized isochronal curves to the nearest harbour (Mataró, Vilanova or Barcelona) during the first third of the $19^{\text {th }}$ century. ${ }^{4}$ Before railroads, the location of every municipality had a deep impact on the economic access to foreign markets. Practically all inland trade had to be carried through cart roads and bridle paths. By comparing maps 1 and 3, the relationship between vine-growing locations and time distances to the seaports becomes apparent.

Agro-climatic endowments acted as conditioning variables that mediated in the local responses to population-push and market5-pull drivers. Slope of the land (Map 1) and the texture of soils, rainfall, frost risk, solar radiation, together with altitude and average temperature determined the suitability of different lands for a range of possible crops (see Tello and Badia-Miró 2011)—as shown in some partial versions of our model (Garrabou et al. 2009). However, we always pointed out that income distribution was a missing variable in these earlier papers. Here we are offering what we consider to be a complete version thanks to having been able to include this key variable by founding and fully exploiting a wonderful source, the Repartimiento Personal de la Riqueza Territorial published in 1852. This rather exceptional record lists the names of all owners of land, houses and livestock who were subjected to the cadastral tax. The document adds up the evaluation of their annual taxable incomes to obtain the corresponding tax burden of every municipality (Bravo

${ }^{4}$ To compose the approximate map 3, we have linked the time-distance points with stylized isochronal lines. However, the data set used to test the model only uses the punctual information of the time-distances from one place to another following the cart tracks or bridle paths that existed in 1824-1838.

${ }^{5}$ A detailed discussion of this source could be found in Tello and Badia-Miró (2011). 
Murillo, 1852). All results make it clear that in 1852, per capita land-related incomes were still lower in vine-growing municipalities compared with the ones mainly allocated to cereal cropping and forestry (Table 1).

Map 3. Time distances to the nearest seaport using existing cart roads and bridle paths in the province of Barcelona in 1824-1838

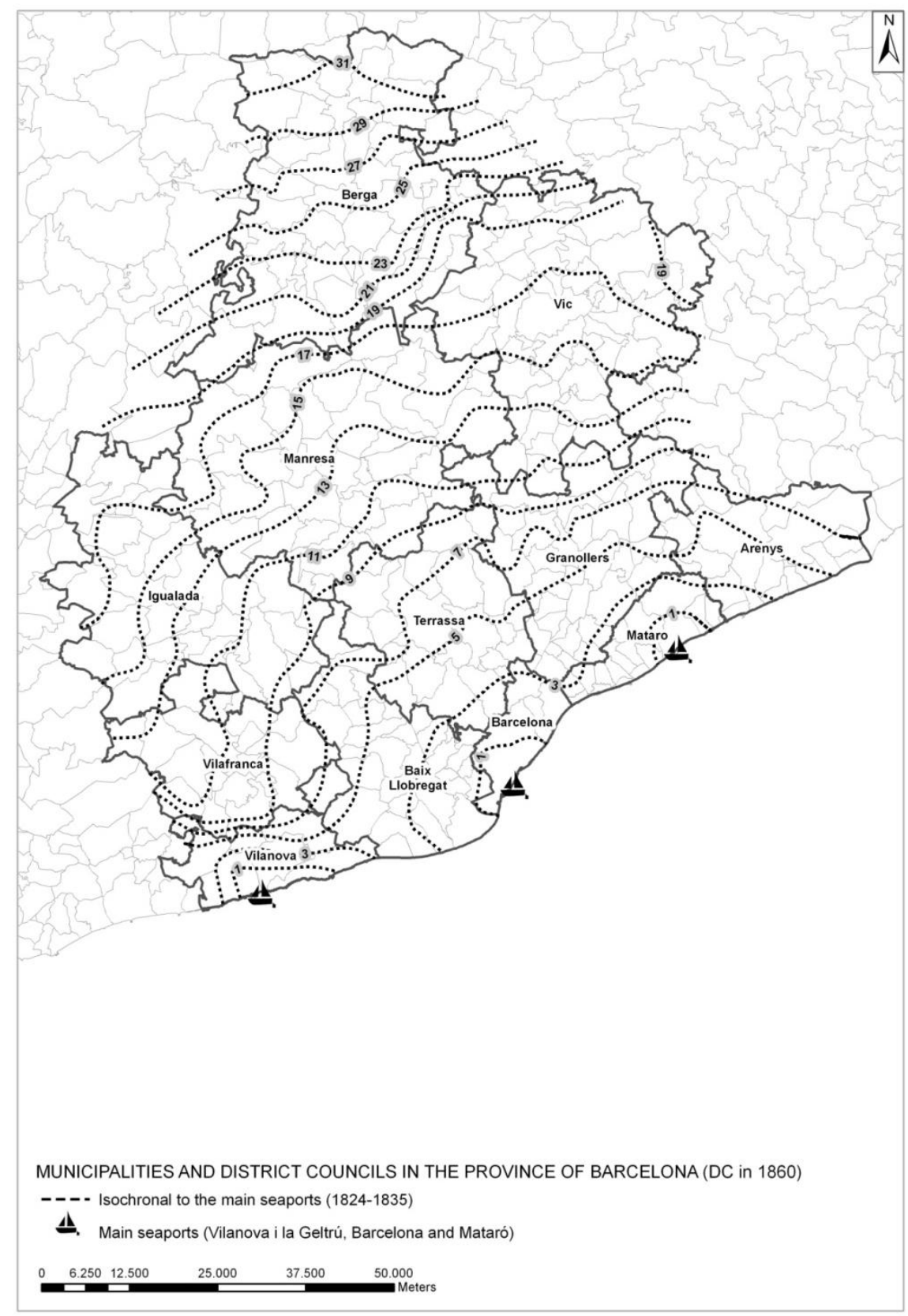

Source: Our own, from two itineraries published before the first Catalan railway was set up in 1848 (Frigola, 1824; Anonymous, 1838), checked with other sources (Bertrán Soler, 1847) or authors (Vilar, 1962; Font, 1999; Pascual, 1999; Herranz-Loncán, 2007; Herranz-Loncán, 2008). 
Table 1. Land-use profiles of inequality in agticultural wealth or income distribution in the municipalities of the province of Barcelona in 1852-1858

\begin{tabular}{l|cc|c|}
\multicolumn{1}{|c|}{ Prevailing land uses } & \multicolumn{2}{|c|}{$\begin{array}{c}\text { Gini indices of the } \\
\text { cadastral valuation } \\
\text { of property }\end{array}$} & $\begin{array}{c}\text { Extraction Ratios expressed as \% of the } \\
\text { actual Theil indices of agricultural income } \\
\text { distribution, compared to the maximum } \\
\text { Inequality Possibility Frontier (IPF) }\end{array}$ \\
\hline all municipalities with land-use data in 1858 & 68.2 & 69.8 & 24.9 \\
mainly winegrowing municipalities & 64.7 & 65.2 & 22.0 \\
mainly cereal cropping & 69.1 & 69.9 & 25.2 \\
mainly allocated to forestry uses of land & 70.1 & 72.0 & 25.0
\end{tabular}

Source: our own, calculated from the Repartimiento Personal de la Riqueza Territorial of 1852 (Library of the University of Barcelona, reference 146-1-II/13), the population census of 1857 (taken from the Centre d'Estudis Demogràfics, http://www.ced.uab.es/), and the Estadística Territorial compiled in 1858 (Muro et al., 2011). Theil indices, Extraction Ratios and the IPF have been calculated for the whole adult male population older than 21, and adding a minimum vital income of 1,500 Spanish reales a year (Tello and Badia-Miró, 2011).

The comparison between the evidence given in Table 1 and Figure 3 leads to a clear distinction between levels and trends. The long-lasting spread of vineyards from the mid-1 $7^{\text {th }}$ century to the beginning of the $19^{\text {th }}$ century through rabassa morta contracts seems to have reduced wealth and income inequality in winegrowing places, at least compared to cereal-cropping or forestry municipalities (Figure 4). As a result, circa 1850 vine-growing municipalities had lesser inequality levels than the rest. However, according to the trends seen in rental-wage ratios, in a given moment from 1790 to 1840 inequality started to rise again in vine-growing municipalities, whereas it diminished in grain-growing areas (Figure 3).

The Gini indices in Table 1 also raise an interesting question: was the lower inequality level in landrelated incomes of vine-growing rural communities simply due to their relative poverty? ${ }^{6}$ To answer this question, we calculated the Theil index of an estimated agricultural income distribution including all adult males, and obtained the corresponding Extraction Ratios (ER) compared to a maximum Inequality Possibility Frontier (IPF) related to per capita income (Milanovic et al., 2011). The results confirm that not only agrarian income inequality was lower in vine-growing municipalities but extraction ratio as well.

\footnotetext{
${ }^{6}$ Our Catalan profile of rural inequality fits the estimates made in the mid-18 $8^{\text {th }}$ century in France by François Quesnay, who attributed to vine-growing peasant-owners the lowest non-wage agricultural income in his Tableau Économique as pointed out by Milanovic (2010). See also the observation that land distribution was more equitable in French vine-growing areas made by Labrousse (1990). Thanks to the revolution, French winegrowers became mainly property-holders, exactly the same status that rabassa sharecroppers sought in Catalonia. Compared with them, the Catalan vine-growers can only be considered as would-be peasants. Nevertheless, their legal and economic status was stronger than other tenants-at-will, or labour-tenants, that existed in several regions of Europe at the time, such as the statartorpare in Sweden, busmennene in Norway, busmaendene in Denmark, or heuerlinge in North-western Germany, as explained in Mörner, M. (1970) and Schlumbohm (1996).
} 
The above contrast between levels and trends may help us to unravel a difficult conundrum. How can social unrest in vine-growing municipalities be explained, knowing that agricultural income was more evenly distributed in them than in any other area in the Barcelona province in the midnineteenth century? The answer lies in the fact that inequality was actually rising again from 1840 onward, thanks to the closure of the vine-planting frontier, whereas vine-growers tried to keep them lower through their lingering collective action.

\section{Running the model}

To test statistically the determinants of vine-growing specialization attained in mid-19th century the following model has been used:

$\operatorname{VSup}_{j}=\alpha_{1}+\alpha_{2} \cdot A G R C L_{j}+\alpha_{3} \cdot M K A C_{j}+\alpha_{4} \cdot I N E Q_{j}+\alpha_{5} \cdot P O B_{j, t-1}+\varepsilon_{j}$

Where $V S u p_{j}$ is the percentage proportion of cropland allocated to vineyards, $A G R C L_{j}$ are a set of agro-climatic variables which could affect vineyard specialization (slope, rainfall, altitude, soil quality, frost risk and agro-climatic suitability indices for growing grapevines), $M K A C_{j}$ captures the Smithian-pull effect through market access (either domestic or foreign) as assessed by time distances to the seaport of Barcelona. $I N E Q_{j}$ captures income inequality considering Theil indices of income inequality for adult male population as a whole, corrected with a subsistence wage income for all working-age men. To improve the robustness of the estimation we tried using Inequality Extraction Ratio, Theil index with no corrections and Gini index, but no better results were obtained. To capture the Boserupian-push we consider a set of population variables, $P O B_{j, t-1}$, i.e., the population rate growth for each municipality between 1787 and 1860, population density at the beginning and at the end of the period. Table 4 summarize the main statistics of the variables used in this exercise.

Finally, a few dummy variables were considered: one for those municipalities which were capital districts, another for those with population densities greater than 70 inhabitants $/ \mathrm{km}^{2}$. In both cases we are assessing the impact of more urban and diversified economies on vine-growing specialization, and a negative sign ought to be expected. We have also considered a dummy to search for a possible positive effect of municipalities having the King as manor, instead of having a member of the nobility or the Church before the manorial system was abolished in 1836-provided that this could entail a more flexible institutional framework. 
Table 2. Main statistic of the variables

\begin{tabular}{l|ccccc}
\multicolumn{1}{c|}{ Variable } & Mean & Minimum & Maximum & Std. Dev. & Unit \\
\hline Vineyard Specialization & 0.418 & 0.000 & 0.954 & 0.318 & Percentage \\
$\begin{array}{l}\text { Population growth } \\
\text { 1787-1860 }\end{array}$ & 0.90 & -2.60 & 3.20 & 0.80 & Percentage \\
Population density 1787 & 75.25 & 2.90 & 1182.71 & 143.09 & Inhab. $/ \mathrm{km}^{\wedge} 2$ \\
Population density 1860 & 114.99 & 8.068 & 2463.83 & 226.11 & Inhab. $/ \mathrm{km}^{\wedge} 2$ \\
Rainfall & 687.08 & 525.00 & 1093.81 & 108.58 & Millimetres \\
Slope & 11.58 & 1.011 & 39.70 & 6.62 & Percentage \\
Altitude & 375.44 & 3.00 & 1395.00 & 288.69 & Metres \\
Distance to Barcelona & 11.99 & 0.00 & 33.00 & 6.87 & Hours \\
Male inequality (Theil) & 0.028 & 0.000 & 0.101 & 0.018 & -
\end{tabular}


Table 5. Explaining vine-growing specialization in the province of Barcelona in the mid-19th century

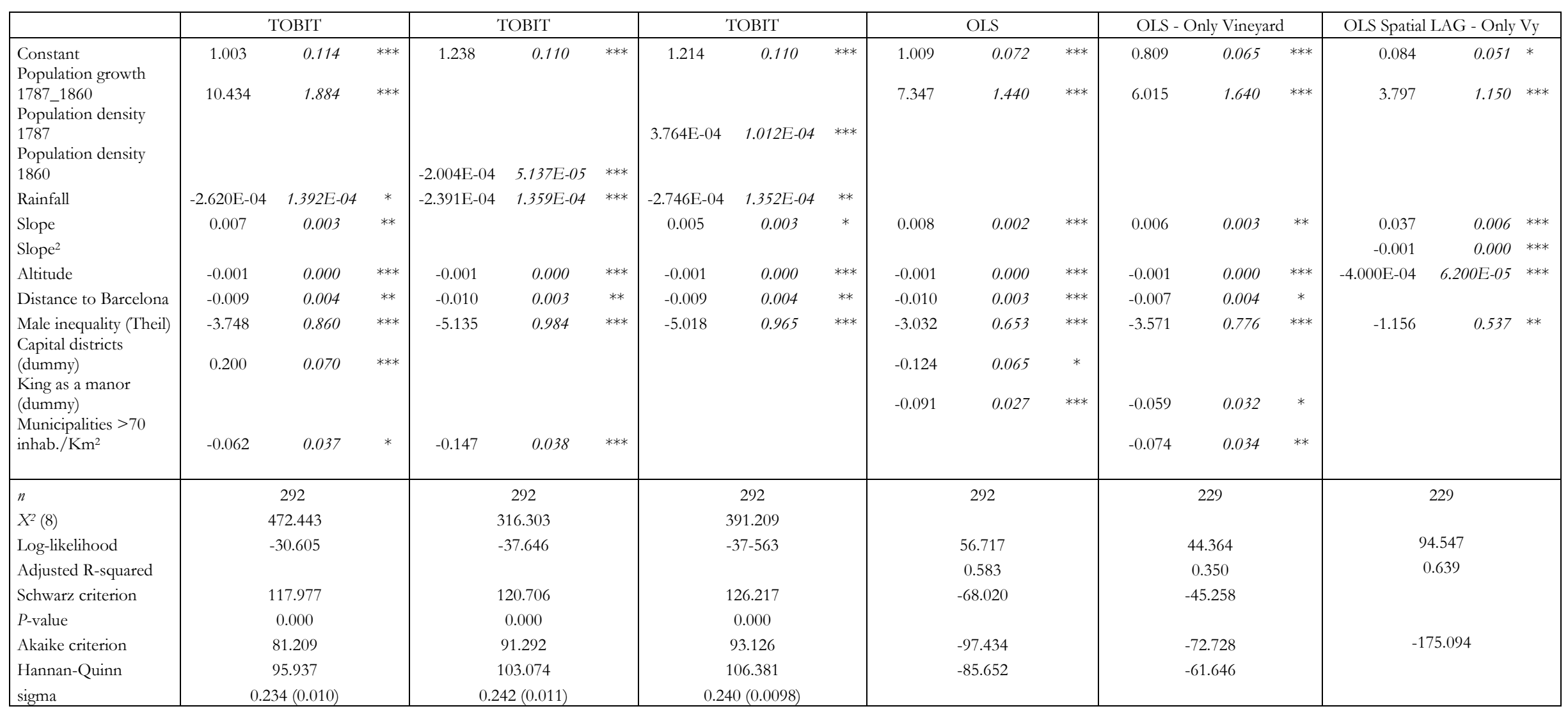

Note: t-ratios are in cursive; $* * * 1, * * 5$, or $* 10 \%$ statistical confidence interval. OLS, ordinary least squares. OLS - Spatial Lag, ordinary least squares considering spatial lags to correct spatial autocorrelation biases. 
Population growth rates between 1787 and 1860 were significant and with the expected sign, so that municipalities with higher rates of population increase before 1860 had higher shares of farmland allocated to vineyards in this date. This confirms the Boserupian-push effect which favoured more labour-intensive crops. The significance of dummy variables related to capital districts or having population densities higher than 70 inhab. $/ \mathrm{km}^{2}$ also suggest the existence of an upper threshold of some 65 inhab. $/ \mathrm{km}^{2}$, a figure above which the population push ceased to foster vine-growing. In order to better capture this higher threshold, we have also considered population densities in 1787 and 1860.No better results were obtained, coefficients were significant, but the positive sign obtained in 1787 turned into a negative sign in 1860 (tables 3 and 4). This suggests that in the mid-nineteenth century the range of population density suitable for growing vineyards had already been attained or even surpassed in most areas of the province of Barcelona with appropriate agro-ecological endowments. Further population increases above that upper threshold entailed a negative impact in vine-growing, thus turning a Boserupian push into a Malthusian overflow. This is a very relevant result that allows us solving the existence of endogeneity problems associated with population variables, given that we can predict from our frontier-led model when a positive or negative sign can be expected.

The market access pull, as measured with time-distances to Barcelona, is always significant and negative except when spatial autocorrelation is considered, thus confirming the Smithian-pulling force of foreign market access in vineyards' spread. The joint impact of these drivers on local landuse changes depended upon other sets of conditioning factors: Agro-ecological suitability and income inequality. No surprises appear when using agro-climatic variables. Rainfall levels are significant and negative, indicating vines were planted in drier lands while moister ones were reserved to cereals and vegetables. The same happens with altitude. Frost risk is significant and positive. Slope is also significant and negative, and the square of the slope has a negative sign showing that it has a decreasing positive impact. All these results confirm that vineyards were planted as a second-best choice in poorer and sloping lands which were less suitable for grain—but not as much as in brushwood and pastures.

We have also repeated the estimates considering the municipal helio-thermal values taken with the Huglin index and the Winkler and Amerine ETI, which are expected to capture the better locations for planting grapevines. Coefficients are not significant, thus reinforcing again the conclusion that vineyard locations cannot be simply explained as a resource allocation owing to agro-climatic endowments. It was the interaction between the whole set of variables that put in motion an 
agency-driven process that created a comparative advantage from the available resources by opening a long-lasting frontier of vineyard planting.

An important leap forward of our model is to have included inequality as a relevant variable for the first time, and it appears to be significant and negative (Male inequality). That is, those municipalities with higher levels of income inequality tended to have lower vine-growing levels. Conversely, the ones with more even income distribution had higher proportions of vineyards in their farmland in the mid-19th century. To test the robustness of this result we have also considered income inequality values only for the cadastral valuation of the taxpayers' properties, and extraction ratios. In all cases the result was the same, showing significant coefficients and the expected sign. ${ }^{7}$

Finally, we have also run some regressions to correct possible spatial autocorrelation problems. As expected, spatial autocorrelation only appears in the impact of time-distances to Barcelona and for average municipal rainfall. All other variables maintain significant coefficients with the expected sign, reinforcing the robustness of the results obtained.

\section{Concluding remarks}

By relying in the stylized facts provided by a very rich historiography, and adopting an innerfrontier model of vineyard planting, we have been able to identify a set of interrelated variables that pushed, pulled or conditioned the Catalan process of vine-growing specialization. Aimed to explain a unique historical process, the analysis also helps to reveal some underlying mechanisms that may have played a role in other cases of agricultural change before and during industrialization—or just the opposite. It tries to understand how a comparative advantage was actually created through an agency-driven process. People acted in Catalonia according to the range of opportunities and resources they had. However, their agency also changed this context and opened new opportunities that altered the prevailing factor endowment by developing second-nature resources from the firstnature ones.

As in any other dynamic process, this vineyard specialization generated feedback loops and turning points that lead to a reverse causation among some of the variables considered, something that entails assuming endogeneity problems. The main way to deal with them has been testing the model as a cross-section analysis of spatial locations of vineyards in the mid-19th century-which is the only time-cut with enough historical sources. The cross-section test 'freezes' the dynamic process in

\footnotetext{
${ }^{7}$ We have also analysed the weight that each term of the equation has in the final outcome. The result reveals that geographical variables such as altitude, rainfall or slope have a slightly greater impact than the others. Among the agency-oriented variables, inequality and market access stand out over the impact of population push.
} 
this specific time-cut, for which our frontier model can predict the expected sign of each variable. Put in this way, "cross-sections are history" (Easterly 2013).

Our results confirm the prime role played by the Smithian market-pulling force combined with the Boserupian population-pushing effect, the two main drivers of land-use change that moved ahead a vine-planting inner frontier. What stands out most from these results is the fact that Catalan vineyard specialization cannot be explained as a simple market-driven resource reallocation, undertaken only according to a given set of agro-climatic features. The active development of second-nature factors was very important, thus confirming the role played by socio-institutional settings and socio-political conflicts related with income inequality. While in the mid-19th century vineyard spread had led to a less unequal rural society, it was also growing faster there than anywhere. This allows explaining why the rabassa morta sharecroppers fought so fiercely during the second half of nineteenth century and up to the Spanish Civil War (1936-39).

True, these Catalan sharecroppers did not become whole owners of the vineyards-except during a while when the Catalan Tenancy Act was passed in 1934, just before the Franco's dictatorship abolished it in 1939. But their struggle was not in vain, and obtained other side-results that were far from negligible. By transforming into vineyards a previous landscape of brushwood and forestlands, othese rabassa morta vitners not only opened a gateway for themselves within Catalan villages and towns. They also gained a place in society and a share of its income. By increasing population numbers and deepening the home market, this helped to turn Catalonia eventually into a late-modern industrious society and an early-contemporary industrial economy.

\section{Acknowledgements}

E.T. has counted with the support given by the Spanish research projects HAR2009-13748-C03 and HAR2012-38920-C02-02, and the Partnership Grant SSHRC 895-2011-1020 on Sustainable Farm Systems: long-term socio-ecological metabolism in Western agriculture funded by the Social Sciences and Humanities Research Council of Canada (2012 -2017). M.B.-M. acknowledges the support of the Spanish research project ECO2012-39169-C03-03 and the "Xarxa de Referència en Economia i Polítiques Públiques" financed by the Catalan government. Both authors are members of the Consolidated Research Group in Economic History and Development (Industry, Business and Sustainability) at the Centre d'Estudis Antoni de Capmany (2009SGR153). We also thank the help received from all members of these research teams, and especially to Ramon Garrabou, Francesc Valls-Junyent, Xavier Cussó, Josep Colomé, Jordi Planas, Lluís Parcerisas, Ricard GarciaOrallo and Pere Pascual. We are also grateful for the criticisms and suggestions to earlier or partial versions of this work made by James Foreman-Peck, Jean-Pascal Bassino, Pedro Lains, Joan Ramon Rosés, Juan Carmona, Alfonso Herranz, Giovanni Federico, Cormac O'Grada, Bob Allen 
and the participants of the Economic History Seminar in Oxford University, and three anonymous reviewers which have improved the final version of the paper. None of them are responsible for our own mistakes.

\section{References}

Acemoglu, D. and Robinson, J. A. (2006). Economic Origins of Dictatorship and Democracy. Cambridge University Press.

Allen, R. C. (2009). The British industrial revolution in global perspective. Cambridge University Press.

Allen, R. C. (2011). Global Economic History: a very short introduction. Oxford University Press.

Anonymous (1838). Itinerario de la mayor parte de los caminos y veredas de las cuatro provincias de Barcelona, Tarragona, Lérida y Gerona, con los pueblos y posadas situadas en las carreteras, y las horas que a paso de tropa distan unos de otros. Barcelona: Imprenta de Manuel Texero.

Austin, G. (2007). Labour and Land in Ghana, 1874-1939: A Shifting Ratio and an Institutional Revolution. Australian Economic History Review 47, 95-120.

Badia-Miró, M., Tello, E., Valls, F. and Garrabou, R. (2010). The grape phylloxera plague as a natural experiment: the unkeep of vineyards in Catalonia (Spain), 1858 - 1935. Australian Economic History Review 50, 1-1.

Badosa, E. (1985). Explotació agrícola $i$ contractes de conreu: 1670-1840. Les finques del clergat de Barcelona. Barcelona, España.: Col·legi Notarial de Barcelona / Virgili i Pagès.

Balcells, A. (1980). El problema agrario en Catalunya: la cuestión rabassaire (1890 - 1936). Madrid: Ministerio de Agricultura, Pesca y Alimentación.

Bertrán Soler, T. (1847). Itinerario descriptivo de Cataluña: comprende la descripción del antiguo Principado, su actual división territorial, militar, eclesiástica y judicial. Barcelona: Imprenta de Oliveres.

Bohlin, J. and Larsson, S. (2007). The Swedish Wage-rental Ratio and Its Determinants, 1877-1926. Australian Economic History Review 47, 49-72.

Boserup, E. (1981). Population and Technological Change: A Study of Long-Term Trends. University of Chicago Press. 
Boserup, E. (2005). The conditions of agricultural growth: the economics of agrarian change under population pressure. New Brunswick, NJ: Aldine.

Bravo Murillo, J. (1852). Real Orden de 10 de febrero de 1852 firmada por el Director General de Contribuciones Directas, Estadísticas y Fincas del Estado. Gaceta de Madrid 12/02/1852, 23.

Carmona, J., Colomé Ferrer, J., Pan-Montojo, J. and Simpson, J. (2001). Viñas, bodegas y mercados: El cambio técnico en la vitivincultura española, 1850-1936. Zaragoza: Prensas Universitarias de Zaragoza.

Carmona, J. and Simpson, J. (1999). The "Rabassa Morta" in Catalan viticulture: the rise and decline of a long-term sharecropping contract, 1670s-1920s. Journal of Economic History 59, 290-315.

Carmona, J. and Simpson, J. (2003). El laberinto de la agricultura española. Instituciones, contratos y organización entre 1850 y 1936. Zaragoza: Prensas universitarias de Zaragoza.

Cerdà, I. (1867). Teoría general de la urbanización y aplicación de sus principios y doctrinas a la reforma y ensanche de Barcelona. Facsimile edition in Madrid: by Estapé, F. (ed), Instituto de Estudios Fiscales.

Cervera, T., Garrabou, R. and Tello, E. (Forthcoming). Política forestal y evolución de los bosques en Cataluña desde el siglo XVIII hasta la actualidad. Investigaciones en Historia Económica.

Colomé, J. (2000). Pequeña explotación agrícola, reproducción de las unidades familiares campesinas y mercado de trabajo en la viticultura mediterránea del siglo XIX: el caso catalán. Revista de Historia Económica - Journal of Iberian and Latin American Economic History 18, 281-307.

Colomé, J. (2013). L'ofensiva dels propietaris contra el contracte de rabassa morta a la comarca del Penedès, 1850-1910. Recerques 66, pp. 1-30.

Colomé, J., Cucurella-Jorba, M. and Valls-Junyent, F. (2010). Poblament i despoblament a la Catalunya vitícola (1760-1910). Butlletí de la Societat Catalana d'Estudis Històrics 21, 137-155.

Colomé, J., Garcia, R., Planas, J. and Valls, F. (2013). L'évolution du prix du vin en Catalogne entre 1680 et 1935. Annales du Midirevue de la France méridionale 281, pp. 29-55.

Colomé, J., Saguer, E. and Vicedo, E. (2002). Las condiciones de reproducción económica de las unidades familiares campesinas en Cataluña a mediados del siglo XIX. In El nivel de vida en 
la España rural, siglos XVIII-XX.(Ed, Martínez Carrión, J.-M.). Alicante: Publicaciones de la Universidad de Alicante, 321-356.

Colomé, J. and Valls-Junyent, F. (2012). Las consecuencias demográficas de la crisis filoxérica en la región vitícola del Penedés (Cataluña). Historia agraria 57, 47-77.

Cronon, W. (1991). Nature's metropolis: Chicago and the Great West. New York: W.W. Norton \& Co Ldt.

Davis, D. R. and Mishra, P. (2007). Stolper-Samuelson Is Dead: And Other Crimes of Both Theory and Data. In Globalization and Poverty(Ed, Harrison, A.). Chicago: University of Chicago Press and National Bureau of Economic Research, 87-107.

Easterly, R. (2013). Cross-sections are history. IZA Discussion paper 7341.

Emery, J. C. H., Inwood, K. and Thille, H. (2007). Hecksher-Ohlin in Canada: New Estimates of Regional Wages and Land Prices. Australian Economic History Review 47, $22-48$.

Ferrer, L. (1987). Pagesos, rabassaires $i$ industrials a la Catalunya central: segles XVIII-XIX. Barcelona, España: Publicacions de l'Abadia de Montserrat.

Font, J. (1999). La formació de la xarxa de transport a Catalunya (1761-1935). Barcelona: Oikos-Tau and Universitat de Barcelona.

Fradera, J. M. (1987). Indústria i mercat: les bases comercials de la indústria catalana moderna (1814-1845). Barcelona: Crítica.

Frigola, V. (1824). Relación de los pueblos de que consta el Principado de Cataluña. Barcelona: Imprenta de la viuda e hijos de D. Antonio Brusi.

Garrabou, R., Planas, J. and Saguer, E. (2000). Sharecropping and the management of large rural estates in Catalonia, 1850-1950. The Journal of Peasant Studies 28, 89-108.

Garrabou, R., Planas, J. and Saguer, E. (2001). Un capitalisme impossible?: la gestió de la gran propietat agraria a la Catalunya contemporánia. Eumo Editorial, Universitat de Vic.

Garrabou, R. and Tello, E. (2002). Salario como coste, salario como ingreso: el precio de los jornales agrícolas en la Cataluña contemporánea (1727-1930). In El nivel de vida en la España rural, siglos XVIII-XX(Ed, Martínez Carrión, J.-M.). San Vicente del Raspeig: Publicaciones de la Universidad de Alicante, 173-176. 
Garrabou, R. and Tello, E. (2010). La interpretación del 'atraso' agrario en El valor geográfico de España (1921) de Emili Huguet del Villar. In Emilio Huguet del Villar, El valor geográfico de España (1921)(Eds, Tello, E. and Sudrià, C.). Barcelona, Spain: Publicacions i Edicions de la Universitat de Barcelona, 35-55.

Garrabou, R., Tello, E. and Cussó, X. (2008). El cambio de usos del suelo en la comarca del Vallès (1850-2000): fuerzas motoras y agentes rectores de la transformación del territorio. In El paisaje en perspectiva histórica: formación y transformación del paisaje en el mundo Mediterráneo.(Eds, Garrabou, R. and Naredo, J. M.). Zaragoza: Prensas Universitarias de Zaragoza, 233-258.

Garrabou, R., Tello, E. and Cussó, X. (2010). Ecological and socio-economic functioning of the Mediterranean agrarian systems in the middle of the nineteenth century. A Catalan case study (the Vallès county, 1850-70). In Agrosystems and labour relations in European Rurals Societies(Eds, Steiner, E. L. and Langthaler, E.). Turnhout, New York: Brepols Publisher.

Garrabou, R., Tello, E., Cussó, X. and Badia-Miró, M. (2009). Explaining agrarian specialization in an advanced organic economy: cereal production, consumption and trade in the province of Barcelona (Spain) in the mid-19 th century. In Markets and Agricultural Change in Europe from the 13th to the 20th Century, Vol. 35 (Ed, Pinilla, V.). Brepols Publishers, 137-172.

Garrabou, R., Planas, J. and Saguer, E. (2012). The management of agricultural estates in Catalonia in the ninteenth and early twentieth century. Agricultural History Review 60, pp. 173-90.

Giralt, E. (1965). El conflicto 'rabassaire'y la cuestión agraria en Cataluña hasta 1936. Revista de Trabajo 7, 51-72.

González de Molina, M. (2002). Environmental constraints on agricultural growth in 19th century Granada (Southern Spain). Ecological Economics 41, pp. 257-70.

Greasley, D., Inwood, K. and Singleton, J. (2007). Factor Prices and Income Distribution in Less Industrialised Economies 1870â $\square$ “1939. Australian Economic History Review 47, 1-5.

Harley, K. (2007). Comments on Factor Prices and Income Distribution in Less Industrialised Economies, 1870â $\square$ "1939: Refocusing on the Frontier. Australian Economic History Review 47, 238-248.

Hayami, Y. and Ruttan, V. (1971). Agricultural Development: An International Perspective. Baltimore: Johns Hopkins Press.

Herranz-Loncán, A. (2007). The spatial distribution of Spanish transport infrastructure between 1860 and 1930. The Annals of Regional Science 41, 189-208. 
Herranz-Loncán, A. (2008). Infraestructuras y crecimiento económico en España, 1850-1935. Fundación de los Ferrocarriles Españoles.

Hunt, R. C. (2000). Labor productivity and agricultural development: Boserup revisited. Human Ecology 28, 251-277.

Johnson, C. H. (1995). The life and death of industrial Languedoc, 1700-1920. New York, USA: Oxford University Press.

Koning, N. (1994). The Failure of Agrarian Capitalism: Agrarian Politics in the UK Germany, the Netherlands and the USA 1846-1919. Routledge.

Krugman, P. (1993). Geography and Trade. Cambridge, MA: The MIT Press.

Labrousse, E. (1990). La crise de l'économie française à la fin de l'Ancien Régime et au début de la Révolution. Paris, France: Presses universitaires de France.

Lindert, P. H. and Williamson, J. G. (2003). Does Globalization Make the World More Unequal? In Globalization in Historical Perspective(Eds, Bordo, M. D., Taylor, A. M. and Williamson, J. G.). Chicago: Chicago University Press., 227-271.

Maddison, A. (2010). Historical Statistics. PIB and population data.

Malanima, P. (2006). Energy Crisis and Growth 1650-1850: The European Deviation in a Comparative Perspective. Journal of Global History 1, 101-121.

Marfany, J. (2010). Is it still helpful to talk about proto-industrialization? Some suggestions from a Catalan case study. The Economic History Review 63, 942-973.

Marfany, J. (2012). Land, Proto-Industry and Population in Catalonia, c. 1680-1829: An Alternative Transition to Capitalism? London: Ashgate Publishing.

Martínez-Galarraga, J. and Prat, M. (2013). Wages and prices in the early Catalan industrialization. In Iberometrics VI. Zaragoza, España.

Milanovic, B. (2005). Worlds apart: measuring international and global inequality. Princeton: Princeton Univ Press.

Milanovic, B. (2010). Level of income and income distribution in mid-18th century France, according to Francois Quesnay. World Bank Policy Research Working Paper Series 10545. 
Milanovic, B. (2011). The Haves and Have-Nots. A Brief Idiosyncratic History of Inequality Around the Globe. New York: Basic Books.

Milanovic, B., Lindert, P. H. and Williamson, J. G. (2011). Pre-Industrial Inequality. The Economic Journal 121, 255-272.

Muro, J. I., Nadal, F. and Urteaga, L. (2011). Estadística Territorial de la Provincia de Barcelona 1859. Pedro Moreno Ramírez: Barcelona: Societat Catalana de Geografia/Institut d'Estudis Catalans.

Mörner, M. (1970). A Comparative Study of Tenant Labor in Parts of Europe, Africa and Latin America 1700-1900: A Preliminary Report of a Research Project in Social History. Latin American Research Review 5, 3-15.

Nadal, J., Benaul Berenguer, J. M. and Sudrià i Triay, C. (2012). Atles de la industrialització de Catalunya : 1750-2010. Barcelona, España: Vicens Vives.

Netting, R. M. C. (1993). Smallholders, householders: farm families and the ecology of intensive, sustainable agriculture. Stanford (CAL): Stanford University Press.

O'Rourke, K. H. and Williamson, J. G. (1999). Globalization and history: the evolution of a nineteenthcentury Atlantic economy. Cambridge, MA.: The MIT Press.

Offer, A. (1991). The First World War: an agrarian interpretation. Clarendon Press.

Olarieta, J. R., Padró, R., Masip, G., Rodríguez-Ochoa, R. and Tello, E. (2011). "Formiguers", a historical system of soil fertilization (and biochar production?). Agriculture, Ecosystems \& Environment 140, 27-33.

Olarieta, J. R., Rodriguez-Valle, F. L. and Tello, E. (2008). Preserving and destroying soils, transforming landscapes: Soils and land-use changes in the Valles County (Catalunya, Spain) 1853â $\square$ “2004. Land Use Policy 25, 474-484.

Pan-Montojo, J. (1994). La bodega del mundo. La vid y el vino en España, 1800-1936 [The cellar of the world. The vine and wine in Spain, 1800-19367. Madrid: Alianza Editorial.

Parcerisas, L. (2012). Cambios en los usos del suelo en El Maresme, provincia de Barcelona, (18502007). Ciudad y territorio: estudios territoriales 173, 511-524.

Pascual, P. (1990). Agricultura i industrialitració a la Catalunya del segle XIX. Barcelona: Crítica.

Pascual, P. (1999). Los Caminos de la era industrial :la construcción y financiación de la red ferroviaria catalana: 1843-1898. Barcelona: Edicions Universitat de Barcelona. 
Pascual, P. (2000). Els Torelló: una família igualadina d'advocats i propietaris. Barcelona.: Fundació Salvador Vives Casajuana/Rafael Dalmau.

Paül, V. (2010). El cambio de los usos agrarios del suelo en el actual ámbito metropolitano de Barcelona (del siglo XVIII a la actualidad). Investigaciones Geográficas 53, 145-188.

Peña, C. (1852). Tratado de estadística territorial y pecuaria, acompañado de un reglamento general para su establecimiento y conservación. Pontevedra: Imprenta de N. Pazos y José Antunez.

Pinilla, V. and Ayuda, M. I. (2007). The International Wine Market, 1850-1938. An Opportunity for Export Growth in Southern Europe? In Wine, Society, and Globalization. Multidisciplinary Perspectives on the Wine Industry(Eds, Campbell, G. and Guibert, N.). New York: Palgrave Macmillan, 179â $\square$ “199.

Planas, J. and Valls-Junyent, F. (2011). ¿Por qué fracasaban las cooperativas agrícolas? Una respuesta a partir del análisis de un núcleo de la Cataluña rabasaire. Investigaciones de Historia Económica - Journal of the Spanish Economic History Association 7, 310-321.

Prados de la Escosura, L. (2008). Inequality, poverty and the Kuznets curve in Spain, 1850-2000. European Review of Economic History 12, 287-324.

Pujol, J., González de Molina, M. I., Fernández Prieto, L., Gallego, D. and Garrabou, R. (2001). El pozo de todos los males. Sobre el atraso de la agricultura española contemporánea. Barcelona, Espanya.: Crítica.

Ringrose, D. R. (1970). Transportation and economic stagnation in Spain, 1750 - 1850. Durham.

Ringrose, D. R. (1983). Madrid and the Spanish Economy: 1560 - 1850. University of Catalonia Press.

Rosés, J. R., Martínez-Galarraga, J. and Tirado, D. A. (2010). The upswing of regional income inequality in Spain (1860-1930). Explorations in Economic History 47, 244-257.

Roy, T. (2007). Globalisation, Factor Prices, and Poverty in Colonial India. Australian Economic History Review 47, 73-94.

Santiago-Caballero, C. (2011). Income inequality in central Spain, 1690-1800. Explorations in Economic History 48, 83-96.

Schlumbohm, J. (1996). Micro-history and the macro-model of the European Demographic System in pre-industrial times: Life course patterns in the parish of Belm (Nortwest Germany). Seventeenth to the Nineteenth centuries. The history of the Family, An International Quarterly 1, $81-95$. 
Shanahan, M. P. and Wilson, J. K. (2007). Measuring Inequality Trends in Colonial Australia Using Factor-price Ratios: The Importance of Boundaries. Australian Economic History Review 47, 621.

Sieferle, R. P. (2001). The Subterranean Forest. Cambridge, Massachussets: White Horse Press.

Simpson, J. (1995). Spanish Agriculture: The Long Siesta, 1765 - 1965. Cambridge, MA: Cambridge University Press.

Simpson, J. (2011). Creating Wine: The emergence of a world industry, 1840-1914. Princeton, NJ: Princeton University Press.

Stiglitz, J. E. (2012). The Price of Inequality: How Today's Divided Society Endangers Our Future. WW Norton.

Sudria, C. and Pascual, P. (1999). Financing a railway mania: capital formation and the demand for money in Catalonia, 1840 - 1866. Financial History Review 6, 127-145.

Sudrià, C. (1979). L'ingrés agrícola a la Plana de Vic el segle XVIII. Les rendes d'origen agrari. Recerques: història, economia, cultura, 77-101.

Sánchez, A. and Nadal, J. (1998a). En los orígenes del éxito algodonero catalán [In the origins of the Catalan cotton success]. In De la fibre a la fripe. Le textile dans la France meridionale et $l \square \mathrm{TM}$ Europe mediterraneene, XVIIIe-XXe siécles [From the fibre to the frippery. Textiles in southern France and Mediterranean Europe, 18th-20th centuries]. Montpelier: Université Paul Valéry, 3557.

Sánchez, A. and Nadal, J. (1998b). En los orígenes del éxito algodonero catalán [In the origins of the Catalan cotton success]. In De la fibre a la fripe. Le textile dans la France meridionale et $l \square \mathrm{TM}$ Europe mediterraneene, XVIIIe-XXe siecles [From the fibre to the frippery. Textiles in southern France and Mediterranean Europe, 18th-20th centuries]. Montpelier: Université Paul Valéry, 3557.

Tello, E. (1995a). Cervera i la Segarra al segle XVIII: en els origens d'una Catalunya pobra, 1700 - 1860. Lleida: Pagès.

Tello, E. (1995b). El fin de la expansión agraria en la Cataluña del siglo XVIII: factores económicos y crisis social. Agricultura y sociedad 74, 109-157.

Tello, E. (1997). La conflictividad social en el mundo rural catalán, del Antiguo Régimen a la Revolución liberal, 1720-1833. Historia Agraria 7, 89-104. 
Tello, E. and Badia-Miró, M. (2011). Land-use profiles of agrarian income and land ownership inequality in the province of Barcelona in mid-nineteenth century. Working Paper of the Spanish Agricultural Society DT-SEHA 11-01.

Tello, E., Badia-Miró, M., Cussó, X., Garrabou, R. and Valls, F. (2008). Explaining vineyard specialization in the province of Barcelona (Spain) in the mid-19th century. Documents de Treball.Facultat Economia i Empresa.Universitat de Barcelona 08-201.

Tello, E., Garrabou, R., Cussó, X., Olarieta, J. R. and Galán, E. (2012). Fertilizing Methods and Nutrient Balance at the End of Traditional Organic Agriculture in the Mediterranean Bioregion: Catalonia (Spain) in the 1860s. Human Ecology, 1-15.

Tonietto, J. and Carbonneau, A. (2004). A multicriteria climatic classification system for grapegrowing regions worldwide. Agricultural and Forest Meteorology 124, 81âa “97.

Torras, J. (1996). Productes vitícoles i integració mercantil a Europa, segles XV - XVIII. Estudis d'Història Econòmica 14, 23-33.

Valls-Junyent, F. (1996). La dinàmica del canvi agrari a la Catalunya interior. L'Anoia, 1720-1860. Publicacions de l'Abadia de Montserrat.

Valls-Junyent, F. (1997). Contractació a rabassa morta i conjuntura vitícola a Catalunya, 1720-1850. Estudis Històrics i Documents dels Arxius de Protocols XV, 229-234.

Valls-Junyent, F. (2001). Cambios estructurales en el comercio vinícola y progresos en la ciencia enológica en Cataluña durante el primer tercio del siglo XIX. In Viñas, bodegas y mercados. El cambio técnico en la vitivinicultura española(Eds, Carmona, J., Colomé, J., Pan-Montojo, J. and Simpson, J.). Zaragoza: Prensas Universitarias de Zaragoza, 239- $\square$ “264.

Valls-Junyent, F. (2003). La Catalunya atlàntica: aiguardent $i$ teixits a l'arrencada industrial catalana. Eumo editorial.

Valls-Junyent, F. (2004). Viticulture et industrialisation en Europe du Sud: Les cas du Languedoc, du Portugal et de la Catalogne. Domitia 5, 41-51.

Valls-Junyent, F. (2007). Compitiendo con el champagne. La industria española de los vinos espumosos antes de la Guerra Civil. Revista de Historia Industrial, 47-79.

Valls-Junyent, F. (2011). Échec et succès de l'industrialisation dans les territoires du vignoble. Languedoc versus Catalogne. In Les chemins de l'industrialisation en Espagne et en France. Les 
PME et le développement des territoires (XVIIIe - XXI siècles)(Eds, Le Bot, F. and Perrin, C.). Bruxelles: PIE Peter Lang, 249-274.

Van Zanden, J. L. (1995). Tracing the Beginning of the Kuznets Curve: Western Europe during the Early Modern Period. Economic History Review 48, 643-664.

Vicedo, E. (1991). Les terres de Lleida i el desenvolupament català del set-cents: producció, propietat i renda. Barcelona, Espanya: Crítica.

Vilar, P. (1962). La Catalogne dans l'Espagne moderne: Recherches sur les fondements économiques des structures nationales. Parí-s: SEVPEN.

Vilar, P. (1974). La Catalunya industrial: reflexions sobre una arrencada i sobre un destí. Recerques. Història, economia i cultura 3, 7-22.

Warde, P. (2007). Energy Consumption in England and Wales, 1560-2000. Roma, Italy: Consiglio Nazionale delle Ricerche / Istituto di studi sulle Società del Mediterraneo.

Williamson, J. G. (2006). Globalization and the Poor Periphery before 1950. Cambridge, MA.: The MIT Press.

Williamson, J. G. (2011). Trade and Poverty: When the Third World Fell Bebind. Cambridge, MA: MIT Press.

Wrigley, E. A. (2010). Energy and the English industrial revolution. Cambridge, MA.: Cambridge University Press. 


\section{Appendix}

Table A1.Population increase and population densities in the districts of the province of Barcelona (1718-1857)

\begin{tabular}{|c|c|c|c|c|c|c|c|c|c|c|c|}
\hline Districts & $\begin{array}{l}\text { Inhabi- } \\
\text { tants }\end{array}$ & $\begin{array}{c}1718 \\
\text { Inhab- } \\
\text { itants } \\
/ \mathrm{km}^{2}\end{array}$ & $\begin{array}{c}\text { ha } \\
\text { /inhabi- } \\
\text { tant }\end{array}$ & $\begin{array}{c}\text { Inhabi- } \\
\text { tants }\end{array}$ & $\begin{array}{l}\text { Inhab- } \\
\text { itants } \\
/ \mathrm{km}^{2}\end{array}$ & $\begin{array}{c}\text { ha } \\
\text { /inhabi- } \\
\text { tant }\end{array}$ & $\begin{array}{c}\text { Inhabi- } \\
\text { tants }\end{array}$ & $\begin{array}{c}\text { Inhab- } \\
\text { itants } \\
/ \mathrm{km}^{2}\end{array}$ & $\begin{array}{c}\text { ha } \\
\text { /inhabi- } \\
\text { tant }\end{array}$ & $\begin{array}{c}\text { yearly } \\
\text { growth } \\
\text { rates } \\
1718 \text { - } \\
1858 \\
\end{array}$ & $\begin{array}{c}\text { yearly } \\
\text { growth } \\
\text { rates } \\
1787 \text { - } \\
1858 \\
\end{array}$ \\
\hline Barcelona & 36,781 & 234.4 & 0.43 & 125,745 & 801.4 & 0.12 & 247,942 & $1,580.30$ & 0.06 & $1.4 \%$ & $1.0 \%$ \\
\hline Arenys & 14,599 & 36.6 & 2.73 & 30,070 & 75.3 & 1.33 & 37,063 & 92.9 & 1.08 & $0.7 \%$ & $0.3 \%$ \\
\hline Berga & 12,121 & 10 & 10.03 & 19,299 & 15.9 & 6.3 & 39,632 & 32.6 & 3.07 & $0.8 \%$ & $1.0 \%$ \\
\hline Granollers & 16,819 & 27.7 & 3.61 & 22,819 & 37.5 & 2.66 & 38,521 & 63.4 & 1.58 & $0.6 \%$ & $0.7 \%$ \\
\hline Igualada & 12,354 & 12.5 & 8.02 & 25,714 & 26 & 3.85 & 54,934 & 55.5 & 1.8 & $1.1 \%$ & $1.1 \%$ \\
\hline Manresa & 16,586 & 14.7 & 6.8 & 25,692 & 22.8 & 4.39 & 53,057 & 47 & 2.13 & $0.8 \%$ & $1.0 \%$ \\
\hline Mataró & 16,639 & 92.2 & 1.08 & 29,986 & 166.2 & 0.6 & 43,164 & 239.3 & 0.42 & $0.7 \%$ & $0.5 \%$ \\
\hline Sant Feliu & 8,110 & 17.1 & 5.84 & 24,207 & 51.1 & 1.96 & 39,588 & 83.5 & 1.2 & $1.1 \%$ & $0.7 \%$ \\
\hline Terrassa & 9,937 & 17.3 & 5.79 & 20,552 & 35.7 & 2.8 & 52,737 & 91.7 & 1.09 & $1.2 \%$ & $1.3 \%$ \\
\hline Vic & 21,740 & 20.1 & 4.98 & 40,954 & 37.8 & 2.64 & 59,618 & 55.1 & 1.82 & $0.7 \%$ & $0.5 \%$ \\
\hline Vilafranca & 11,721 & 17.6 & 5.67 & 28,837 & 43.4 & 2.31 & 48,079 & 72.3 & 1.38 & $1.0 \%$ & $0.7 \%$ \\
\hline TOTALS & 177,407 & 23.7 & 4.23 & 393,875 & 52.5 & 1.9 & 714,335 & 95.3 & 1.05 & $1.0 \%$ & $0.8 \%$ \\
\hline $\begin{array}{l}\text { Outside } \\
\text { Barcelona } \\
\text { District }\end{array}$ & 140,626 & 19.2 & 5.2 & 268,130 & 36.6 & 2.73 & 466,393 & 63.7 & 1.57 & $0.9 \%$ & $0.8 \%$ \\
\hline
\end{tabular}

Sources: Our own, based on population census taken from Centre d'Estudis Demogràfics

\section{(http://www.ced.uab.es/index.php).}

\section{Rental-wage ratio}

An approximation to the ratio between landowners' rents earned and one of the various incomes of less-skilled agrarian workers (who earned these wages + other income derived from their own work in small plots of land owned by them, or leased through a "rabassa morta" contract...). We have obtained data for two zones:

\section{Mainly vine-growing}

1. Rent payments in kind corresponding to sharecropping portions of wine, converted into pesetas, taken from "Parceries de les Torres de l'Hospital, 1720-1799, i de les Torres de Badalona, Cornellà i Esplugues" by Vilar (1965, p. 595 i 604-605), for the period 17201777.

2. Sharecropping rents of wine converted into pesetas from "Parceries de les Torres de l'Hospital, 1720-1799, de les Torres de Cornellà, Esplugues i El Prat" by Vilar (1965, p. 595 i 604-605), for the period 1726-1799.

3. Rents paid in cash to the Marquis of Sentmenat by his administrators of the estates in Palau de Plegamans, for 1788-1822, in Garrabou et al. (2001).

4. Rents paid in cash to the Marquis of Sentmenat by his administrators of the estates in Palau de Plegamans, for 1821-1898, in Garrabou et al. (2001).

5. Series of non-skilled agricultural wages, out of peak seasons, taken from Garrabou and Tello (2002). We have considered here wages for coastal places.

We have transformed all the series into pesetas. For (1) and (2) we have considered the annual sharecropping portions of wine paid as rents in kind given by Vilar (1965). We have transformed to 
hl considering: 1 carrega of wine $=1,2141$ following (Feliu, 1991, p. 18). Then we have converted this rent paid in kind into cash value in pesetas using wine prices from Colomé et al. (2013). For the series (3) and (4) we have considered that 1 lliura $=0,377358$ pessetes (1 lliura $=20$ sous; 1 sou $=0,53$ rals; 1 peseta $=4$ rals). The resulting figures has been smoothed considering 9 years moving averages and transformed to index numbers considering $1740=100$. Rental series resulted from the average of this index numbers. To obtain nominal rental series we have considered the average for series (1) and (2), in 1740 .

\section{Mainly cereal-growing}

1. Annual rent payments in kind corresponding to sharecropping portions of wheat, in quarteres, transformed into cash value in pesetas, for the "Parceries de les Torres de l'Hospital, 1720-1799, de les Torres de Badalona, Cornellà i Esplugues" given by Vilar (1965, p. 595 i 604-605), for the period 1720-1777.

2. Annual rents paid in cash (in lliures) to the landowner corresponding to the sharecropping portion of the harvest get in his estates in the Plana de Vic, given by Sudrià (1979), for the period 1730-1838.

3. Sum of the annual cash rents paid (in lliures) to the owner of five small plots (sorts) and the lands included in a wheat mill in Cervera (La Segarra, inland Catalonia, sometimes irrigated), for the period 1744-1803 and 1808-1810, given by Tello (1995a, 1995b).

4. Annual cash rents paid to the landowner of a estate in the Urgell (inland Catalonia) for 1835-1900 given (in pesetas) by Garrabou et al., (2001).

5. Series of non-skilled agricultural wages, out of peak seasons, taken from Garrabou and Tello (2002). We have considered here wages for inland places.

We have transformed all series into the Spanish currency pesetas. For (1) we have considered the fresh weight in quarteres transformed to lliures following Vilar (1965), and have transformed the lliures into pesetas considering the equivalences of 1 lliura $=0,377358$ pesetes. For (2), (3) and (4) we have converted the lliures into pesetes considering that equivalence. The resulting figures has been smoothed considering 9 years moving averages and transformed to index numbers considering $1740=100$. Rental series resulted from the average of this index numbers. To obtain nominal rental series we have considered the average for series (1) and (2), in 1740. 
Table A2. Rental-wage ratios in cereal growing and vine-growing Catalan areas, 1720-1900

\begin{tabular}{|c|c|c|c|c|c|c|c|c|}
\hline Year & $\begin{array}{c}\mathrm{r}-\mathrm{w} \\
\text { cereal } \\
\text { zone }\end{array}$ & $\begin{array}{c}r-w \text { vine } \\
\text { zone }\end{array}$ & Year & $\begin{array}{c}\mathrm{r}-\mathrm{w} \\
\text { cereal } \\
\text { zone }\end{array}$ & $\begin{array}{c}r-w \text { vine } \\
\text { zone }\end{array}$ & Year & $\begin{array}{c}\mathrm{r}-\mathrm{w} \\
\text { cereal } \\
\text { zone }\end{array}$ & $\begin{array}{l}\mathrm{r}-\mathrm{w} \text { vine } \\
\text { zone }\end{array}$ \\
\hline 1720 & & 0.89 & 1754 & 8.13 & 4.85 & 1788 & 9.87 & 4.22 \\
\hline 1721 & & 0.79 & 1755 & 8.02 & 5.81 & 1789 & 10.28 & 4.03 \\
\hline 1722 & & 0.76 & 1756 & 7.80 & 5.48 & 1790 & 10.61 & 3.55 \\
\hline 1723 & 4.30 & 1.32 & 1757 & 7.74 & 5.22 & 1791 & 10.31 & 3.42 \\
\hline 1724 & 4.25 & 1.73 & 1758 & 7.68 & 5.51 & 1792 & 10.41 & 3.23 \\
\hline 1725 & 4.71 & 1.99 & 1759 & 7.70 & 5.50 & 1793 & 10.23 & 3.05 \\
\hline 1726 & 5.45 & 2.74 & 1760 & 7.74 & 5.79 & 1794 & 10.12 & 3.00 \\
\hline 1727 & 5.98 & 3.10 & 1761 & & 5.68 & 1795 & 9.94 & 2.96 \\
\hline 1728 & 6.34 & 3.24 & 1762 & & 5.47 & 1796 & 9.88 & 2.91 \\
\hline 1729 & 6.46 & 3.28 & 1763 & & 5.65 & 1797 & 9.79 & 2.85 \\
\hline 1730 & 6.63 & 4.68 & 1764 & & 5.64 & 1798 & 9.72 & 2.72 \\
\hline 1731 & 6.87 & 6.05 & 1765 & & 5.58 & 1799 & 9.26 & 2.62 \\
\hline 1732 & 7.33 & 6.70 & 1766 & & 5.71 & 1800 & 9.33 & 2.51 \\
\hline 1733 & 7.98 & 7.90 & 1767 & & 5.62 & 1801 & 9.39 & 2.45 \\
\hline 1734 & 8.42 & 8.51 & 1768 & 8.46 & 5.88 & 1802 & 9.22 & \\
\hline 1735 & 8.38 & 8.49 & 1769 & 8.87 & 5.28 & 1803 & 9.22 & \\
\hline 1736 & 8.03 & 9.60 & 1770 & 8.93 & 5.00 & 1804 & 9.02 & \\
\hline 1737 & 7.87 & 10.49 & 1771 & 8.95 & 4.81 & 1805 & 8.65 & \\
\hline 1738 & 8.01 & 10.81 & 1772 & 8.77 & 4.51 & 1806 & 8.15 & \\
\hline 1739 & 8.11 & 9.83 & 1773 & 8.65 & 4.37 & 1807 & 7.76 & \\
\hline 1740 & 8.07 & 9.22 & 1774 & 8.80 & 4.46 & 1808 & 7.23 & 2.90 \\
\hline 1741 & 7.86 & 9.82 & 1775 & 8.86 & 4.35 & 1809 & 6.92 & 2.86 \\
\hline 1742 & 7.80 & 8.94 & 1776 & 9.17 & 4.34 & 1810 & 6.65 & 2.82 \\
\hline 1743 & 7.90 & 8.48 & 1777 & 9.28 & 3.87 & 1811 & 6.54 & 2.78 \\
\hline 1744 & 8.41 & 8.80 & 1778 & 9.25 & 4.11 & 1812 & 6.46 & 2.74 \\
\hline 1745 & 8.60 & 7.96 & 1779 & 9.04 & 4.64 & 1813 & 6.43 & 2.69 \\
\hline 1746 & 8.77 & 7.81 & 1780 & 9.04 & 4.74 & 1814 & 6.51 & 2.69 \\
\hline 1747 & 8.81 & 8.11 & 1781 & 8.78 & 4.84 & 1815 & 6.53 & 2.69 \\
\hline 1748 & 8.42 & 8.10 & 1782 & 8.88 & 4.66 & 1816 & 6.40 & 2.69 \\
\hline 1749 & 8.53 & 7.39 & 1783 & 9.32 & 4.46 & 1817 & 6.29 & 2.70 \\
\hline 1750 & 8.38 & 6.66 & 1784 & 9.25 & 4.43 & 1818 & 6.48 & 2.42 \\
\hline 1751 & 8.26 & 6.69 & 1785 & 9.41 & 4.65 & 1819 & 6.55 & 2.94 \\
\hline 1752 & 8.13 & 6.73 & 1786 & 9.37 & 4.68 & 1820 & 6.70 & 2.97 \\
\hline 1753 & 8.48 & 6.52 & 1787 & 9.49 & 4.51 & 1821 & 6.54 & 2.89 \\
\hline 1822 & 6.31 & 2.94 & 1849 & 6.77 & 3.52 & 1876 & 2.46 & 4.12 \\
\hline 1823 & 6.28 & 3.00 & 1850 & 6.96 & 3.52 & 1877 & 2.41 & 4.36 \\
\hline 1824 & 8.01 & 2.98 & 1851 & 7.44 & 4.21 & 1878 & 2.28 & 4.58 \\
\hline 1825 & 7.76 & 3.03 & 1852 & 7.70 & 4.75 & 1879 & 2.07 & 4.78 \\
\hline 1826 & 8.14 & 3.11 & 1853 & 7.73 & 5.10 & 1880 & 1.78 & 4.58 \\
\hline 1827 & 8.09 & 3.29 & 1854 & 7.58 & 5.21 & 1881 & 1.43 & 4.44 \\
\hline 1828 & 8.27 & 3.06 & 1855 & 7.84 & 5.51 & 1882 & 1.32 & 4.54 \\
\hline 1829 & 8.28 & 3.02 & 1856 & 7.97 & 5.40 & 1883 & 1.19 & 4.81 \\
\hline 1830 & 8.08 & 3.01 & 1857 & 7.89 & 4.60 & 1884 & 1.55 & 4.80 \\
\hline 1831 & 8.56 & 3.02 & 1858 & 7.51 & 5.57 & 1885 & 1.78 & 4.39 \\
\hline 1832 & 8.37 & 3.00 & 1859 & 7.48 & 5.66 & 1886 & 1.94 & 4.09 \\
\hline 1833 & 8.31 & 3.12 & 1860 & 7.59 & 5.26 & 1887 & 1.90 & 3.87 \\
\hline 1834 & 7.89 & 3.00 & 1861 & 7.14 & 5.07 & 1888 & 1.84 & 3.63 \\
\hline 1835 & 7.73 & 2.89 & 1862 & 6.66 & 4.98 & 1889 & 2.13 & 3.61 \\
\hline 1836 & 7.21 & 2.81 & 1863 & 6.81 & 5.08 & 1890 & 2.42 & 3.52 \\
\hline 1837 & 7.00 & 2.78 & 1864 & 6.61 & 4.61 & 1891 & 2.61 & 3.29 \\
\hline 1838 & 6.31 & 2.70 & 1865 & 6.26 & 5.05 & 1892 & 2.52 & 3.05 \\
\hline 1839 & 6.28 & 2.73 & 1866 & 5.82 & 5.25 & 1893 & 2.71 & 2.97 \\
\hline 1840 & 6.19 & 2.78 & 1867 & 5.54 & 4.54 & 1894 & 2.85 & 2.87 \\
\hline 1841 & 6.40 & 2.77 & 1868 & 5.53 & 4.60 & 1895 & 3.36 & 2.74 \\
\hline 1842 & 6.72 & 2.50 & 1869 & 2.85 & 4.45 & 1896 & 3.59 & 2.69 \\
\hline 1843 & 6.43 & 2.47 & 1870 & 3.33 & 4.37 & 1897 & 3.80 & 2.45 \\
\hline 1844 & 6.56 & 2.48 & 1871 & 3.88 & 4.44 & 1898 & 4.25 & 2.27 \\
\hline 1845 & 6.47 & 2.47 & 1872 & 4.03 & 4.50 & 1899 & 4.48 & 2.16 \\
\hline 1846 & 6.66 & 2.59 & 1873 & 3.95 & 4.63 & & & \\
\hline 1847 & 6.39 & 2.83 & 1874 & 3.18 & 3.93 & & & \\
\hline 1848 & 6.72 & 3.54 & 1875 & 2.71 & 3.94 & & & \\
\hline
\end{tabular}


Sources: Our own, obtained from series of land rents in vine-growing or grain-growing Catalan areas published by several authors (Vilar 1962; Ferrer 1987; Vicedo 1991; Tello 1995; Sudrià 1979; Pascual 2000; Garrabou et al. 2001), divided by the series of agricultural wages reconstructed by Garrabou and Tello (2002). 